\title{
Characterisation of an inlet pre-injector laser-induced fluorescence instrument for the measurement of atmospheric hydroxyl radicals
}

\author{
A. Novelli ${ }^{1}$, K. Hens ${ }^{1}$, C. Tatum Ernest ${ }^{1}$, D. Kubistin ${ }^{1,3}$, E. Regelin ${ }^{1}$, T. Elste ${ }^{2}$, C. Plass-Dülmer ${ }^{2}$, M. Martinez ${ }^{1}$, \\ J. Lelieveld ${ }^{1}$, and H. Harder ${ }^{1}$ \\ ${ }^{1}$ Atmospheric Chemistry Dept., Max Planck Institute for Chemistry, 55128 Mainz, Germany \\ ${ }^{2}$ German Weather Service, Meteorological Observatory Hohenpeissenberg (MOHp), Albin-Schwaiger-Weg 10, \\ 83282 Hohenpeissenberg, Germany \\ ${ }^{3}$ University of Wollongong, School of Chemistry, Wollongong, NSW, Australia \\ Correspondence to: H. Harder (hartwig.harder@mpic.de)
}

Received: 8 January 2014 - Published in Atmos. Meas. Tech. Discuss.: 28 January 2014

Revised: 5 September 2014 - Accepted: 8 September 2014 - Published: 8 October 2014

\begin{abstract}
Atmospheric measurements of hydroxyl radicals $(\mathrm{OH})$ are challenging due to a high reactivity and consequently low concentration. The importance of $\mathrm{OH}$ as an atmospheric oxidant has motivated a sustained effort leading to the development of a number of highly sensitive analytical techniques. Recent work has indicated that the laser-induced fluorescence of the $\mathrm{OH}$ molecules method based on the fluorescence assay by gas expansion technique (LIF-FAGE) for the measurement of atmospheric $\mathrm{OH}$ in some environments may be influenced by artificial $\mathrm{OH}$ generated within the instrument, and a chemical method to remove this interference was implemented in a LIF-FAGE system by Mao et al. (2012). While it is not clear whether other LIF-FAGE instruments suffer from the same interference, we have applied this method to our LIF-FAGE HORUS (Hydroxyl Radical Measurement Unit based on fluorescence Spectroscopy) system, and developed and deployed an inlet pre-injector (IPI) to determine the chemical zero level in the instrument via scavenging the ambient $\mathrm{OH}$ radical.

We describe and characterise this technique in addition to its application at field sites in forested locations in Finland, Spain and Germany. Ambient measurements show that $\mathrm{OH}$ generated within the HORUS instrument is a non-negligible fraction of the total $\mathrm{OH}$ signal, which can comprise 30 to $80 \%$ during daytime and 60 to $100 \%$ during the night. The contribution of the background $\mathrm{OH}$ varied greatly between measurement sites and was likely related to the type and concentration of volatile organic compounds (VOCs) present at each particular location. Two inter-comparisons in contrast-
\end{abstract}

ing environments between the HORUS instrument and two different chemical ionisation mass spectrometers (CIMS) are described to demonstrate the efficacy of IPI and the necessity of the chemical zeroing method for our LIF-FAGE instrument in such environments.

\section{Introduction}

The hydroxyl radical, $\mathrm{OH}$, plays a central role in the chemistry of the troposphere, where it acts as the main daytime oxidising agent, initiating the photochemical degradation of many chemical species emitted by natural and anthropogenic sources. In the lower troposphere the primary $\mathrm{OH}$ radical formation is dominated by photolysis of ozone and subsequent reaction of the excited oxygen atom with water vapour (Levy, 1971). Minor primary sources are the photolysis of nitrous acid and hydrogen peroxide and ozonolysis of unsaturated carbon compounds. Once formed, the $\mathrm{OH}$ radical reacts rapidly with many atmospheric trace gas species converting a large fraction of the volatile organic matter (Levy, 1974). The ambient measurement of $\mathrm{OH}$ is therefore a good test of proposed chemical mechanisms postulating the importance of chemical species and/or processes in the atmosphere. The $\mathrm{OH}$ radical is usually measured in the field with one of three techniques: differential optical absorption spectroscopy (DOAS; Perner et al., 1987) via absorption of light by OH, chemical ionisation mass spectrometry (CIMS; Eisele and Tanner, 1991) via the detection of $\mathrm{H}_{2} \mathrm{SO}_{4}$ after the oxidation 
of $\mathrm{SO}_{2}$ by atmospheric $\mathrm{OH}$, and laser-induced fluorescence (LIF-FAGE; Hard et al., 1984) via the detection of OH radical fluorescence after laser excitation. Several comparison campaigns have been performed, both on ground (Hofzumahaus et al., 1998; Schlosser et al., 2007) and aircraft (Eisele et al., 2001; Ren et al., 2012), to test the consistency and performance of the different techniques and have generally shown good agreement. However, a number of recent measurements performed by LIF-FAGE instruments in VOC-rich environments have shown considerably higher values of $\mathrm{OH}$ radicals than can be accounted for by well-established chemical mechanisms (Faloona et al., 2001; Lelieveld et al., 2008; Ren et al., 2008; Hofzumahaus et al., 2009; Kubistin et al., 2010; Whalley et al., 2011). These model-measurement disagreements have prompted the discovery of new chemical paths (Dillon and Crowley, 2008; Peeters et al., 2009; da Silva, 2010a, b, c; Crounse et al., 2011) and the development of alternative chemical mechanisms to account for the discrepancies (Lelieveld et al., 2008; Hofzumahaus et al., 2009; Peeters et al., 2009; Peeters and Müller, 2010; Taraborrelli et al., 2012). At least in part, the disagreement between models and measurements could be related to the measurement technique. LIF instruments can suffer from a number of well-characterised interferences, such as $\mathrm{OH}$ generated by the laser pulse from species like ozone, acetone, or $\mathrm{H}_{2} \mathrm{O}_{2}$, as well as spectral interferences from, for example, naphthalene and $\mathrm{SO}_{2}$. When present, these can be corrected for (Holland and Hessling, 1995; Martinez et al., 2004; Ren et al., 2004; Kubistin, 2009). Recent work by Mao et al. (2012) suggested that, at least in some LIF-FAGE designs and possibly depending on the characteristics of the environment, a process not currently accounted for may generate $\mathrm{OH}$ within the low-pressure side of the instrument. The authors report the measurement of $\mathrm{OH}$ radicals in a Ponderosa pine plantation in the California Sierra Nevada Mountains with the deployment of a chemical zero-level system in parallel with the traditional FAGE method.

In this paper, we describe the characterisation and application of such a chemical zero system (inlet pre-injector, IPI) to the HORUS instrument, following the design of Mao et al. (2012), to address the possible role of internally formed $\mathrm{OH}$ in our system. In addition, we also describe how the atmospheric $\mathrm{OH}$ concentration is determined with the new modification of the instrument in three field measurements that include two comparisons of the Mainz IPI-LIF-FAGE instrument with CIMS measurements of $\mathrm{OH}$ in chemically distinct environments.

\section{Methodology}

\subsection{Mainz LIF-FAGE description}

The LIF-FAGE instrument (HORUS) in use at the Max Planck Institute for Chemistry, Mainz, is based on the design of GTHOS (Ground Tropospheric Hydrogen Oxide Sensor)

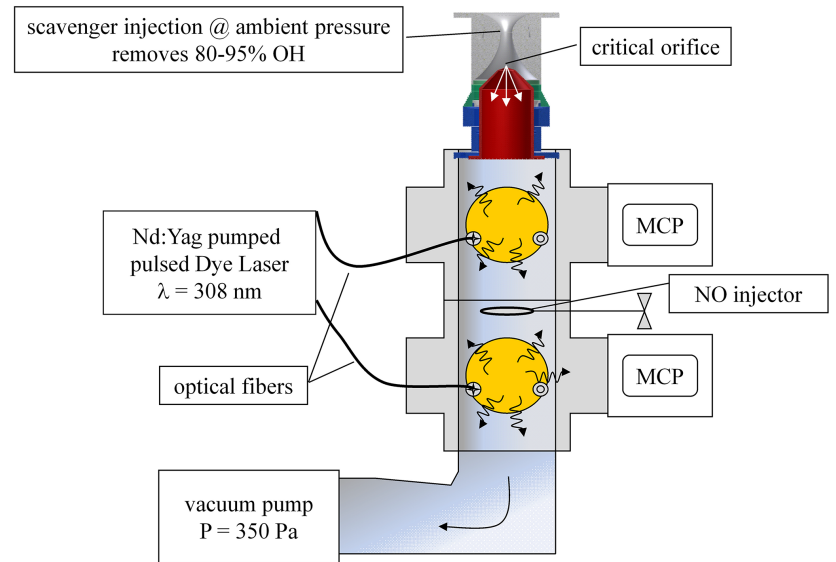

Figure 1. HORUS instrument setup scheme with IPI. The ambient air is sampled through IPI where an $\mathrm{OH}$ scavenger is added periodically and is then sampled by the instrument inlet through a critical orifice. In the first cell, $\mathrm{OH}$ is excited by a laser pulse at around 308 $\mathrm{nm}$ and the fluorescence is detected by an MCP. Directly in front of the second cell a mixture of $\mathrm{NO}$ with nitrogen is injected and $\mathrm{HO}_{2}$ is detected after conversion into $\mathrm{OH}$. The total pressure inside the instrument is maintained around $350 \mathrm{~Pa}$.

described by Faloona et al. (2004) and is described in detail by Martinez et al. (2010). The instrument consists of three parts: the inlet and detection system, the laser system and the vacuum system (Fig. 1). The air is drawn at $\sim 7 \mathrm{~L} \mathrm{~min}^{-1}$ through a critical orifice (1 mm diameter) and $\mathrm{OH}$ is selectively excited by pulsed UV light at around $308 \mathrm{~nm}$ on resonance with the $\mathrm{Q}_{1}(2)$ transition line $\left(\mathrm{A}^{2} \Sigma^{+}-\mathrm{X}^{2} \Pi, v^{\prime}=0\right.$ $\left.v^{\prime \prime}=0\right)$. The laser pulse is directed into a multipass "White Cell" (White, 1942) crossing the detection volume 32 times to increase the sensitivity. The fluorescence signal from the excited hydroxyl radicals is detected at low pressure $(\sim 300-$ $500 \mathrm{~Pa}$ ). As the fluorescence is detected at similar wavelengths as the excitation, a time-gated photon counting technique using micro-channel plate detectors (MCP) is used. The UV light for excitation of the hydroxyl radicals is provided by a Nd: YAG pumped, pulsed, tunable dye laser system (Wennberg et al., 1994; Martinez et al., 2010) operated at a pulse repetition frequency of $3 \mathrm{kHz}$. The instrument has two consecutive detection cells: in the first cell $\mathrm{OH}$ radicals are detected, and in the second cell hydroperoxyl radicals $\left(\mathrm{HO}_{2}\right)$ are detected via the conversion of $\mathrm{HO}_{2}$ to $\mathrm{OH}$ by the addition of NO. The calibration of the instrument is achieved via production of a known amount of $\mathrm{OH}$ and $\mathrm{HO}_{2}$ from the photolysis of water at $185 \mathrm{~nm}$ using a mercury lamp. A more detailed description of the instrument calibration is reported by Martinez et al. (2010). The fluorescence background signal of the instrument is measured by tuning the excitation laser on (online signal, $\mathrm{Sig}^{\mathrm{on}}$ ) and off (offline signal, $\mathrm{Sig}^{\text {off }}$ ) resonance with the $\mathrm{OH}$ transition line at $308 \mathrm{~nm}$ (Fig. 2a). The spectra of the measured atmospheric $\mathrm{OH}$ is compared with the one obtained from a reference cell in order to rule 

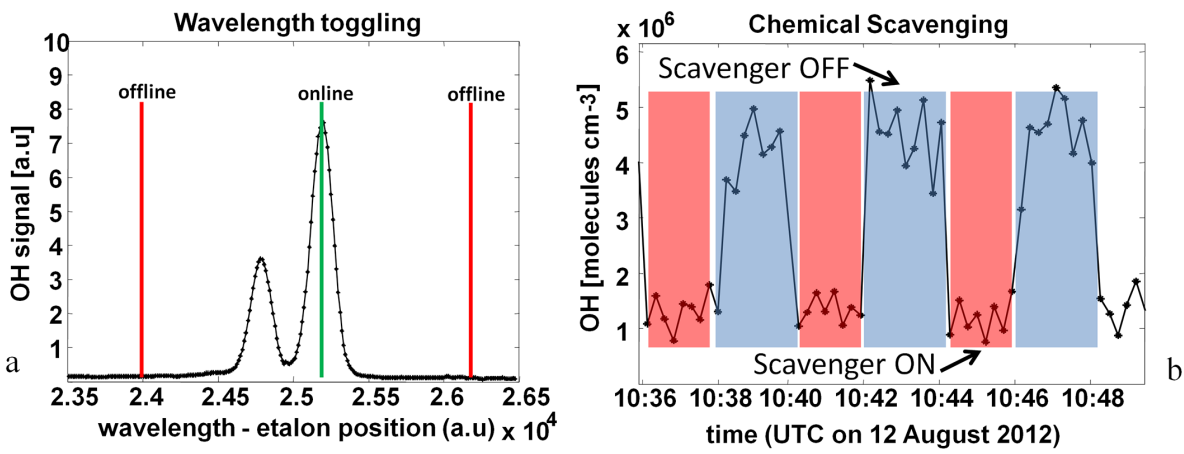

Figure 2. (a) HORUS instrumental fluorescence background signal is detected by tuning the excitation laser on (green line) and off resonance (red lines) with the $\mathrm{OH}$ line at $308 \mathrm{~nm}$; (b) the background $\mathrm{OH}$ signal is obtained by injecting an $\mathrm{OH}$ scavenger periodically in front of the inlet (red shaded area). The blue shaded area represents the total $\mathrm{OH}$ signal. The atmospheric $\mathrm{OH}$ is obtained from the difference between the two.

out possible fluorescence signal due to species that fluoresce at similar wavelengths (such as naphthalene and $\mathrm{SO}_{2}$ ). During all three measurement campaigns described in this paper, the HORUS instrument was equipped with a $14 \mathrm{~cm}$ inlet resulting in a residence time of the air between the pinhole and the detection cell of $2.5 \mathrm{~ms}$ (Novelli et al., 2014). Laser power and pressure at the cell were, respectively, $\sim 4 \mathrm{~mW}$ and $\sim 310$ Pa during the campaigns in Finland and Spain and $\sim 9 \mathrm{~mW}$ and $380 \mathrm{~Pa}$ during the campaign in Germany.

\subsection{Inlet Pre-Injector (IPI)}

Figure 3 shows a schematic cross-section of IPI currently in use as part of the HORUS instrument. The purpose of IPI is the addition of an $\mathrm{OH}$ scavenger to remove the atmospheric $\mathrm{OH}$ before it is sampled by the inlet to account for an $\mathrm{OH}$ signal generated within the instrument. Before the introduction of IPI, the atmospheric OH concentration was obtained by multiplying the $\mathrm{OH}$ fluorescence signal (OHF), obtained from the difference between fluorescence online and fluorescence offline signals, by the total instrument sensitivity $(S)$. The total instrument sensitivity depends on many parameters such as laser power, efficiency of the detector, temperature and humidity (Martinez et al., 2004), and is determined by performing calibrations on a regular basis:

$\mathrm{OHF}=\left(\mathrm{Sig}^{\text {on }}-\mathrm{Sig}^{\text {off }}\right)$

$\mathrm{OH}=S \cdot \mathrm{OHF}$

With IPI (Fig. 2b), the instrument is also cycled every $2 \mathrm{~min}$ between injection of the scavenger (background $\mathrm{OH}$ fluorescence signal, $\mathrm{OHF}_{\mathrm{bg}}$ ) and no injection (total $\mathrm{OH}$ fluorescence signal, $\left.\mathrm{OHF}_{\text {tot }}\right)$. The atmospheric $\mathrm{OH}$ concentration $\left(\mathrm{OH}_{\mathrm{atm}}\right)$ is then obtained by multiplying the difference between the total $\mathrm{OH}$ fluorescence signal and the background $\mathrm{OH}$ fluorescence signal by the instrument sensitivity and by a factor

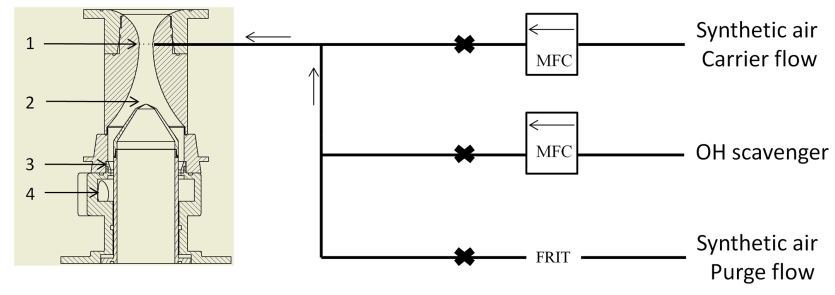

Figure 3. Inlet pre-injector (IPI) scheme. The injection of the scavenger is achieved via eight $0.5 \mathrm{~mm}$ holes (Label 1) positioned $5 \mathrm{~cm}$ above the pinhole of the inlet (Label 2). The scavenger is carried through IPI with $\sim 4000 \mathrm{sccm}$ of synthetic air. The residence time in IPI after the injection of the scavenger is $\sim 4 \pm 0.5 \mathrm{~ms}$ to scavenge between 80 and $95 \%$ of the atmospheric $\mathrm{OH}$, depending on the scavenger concentration. Label 3 indicates the position of a metallic grid. Label 4 shows the connection to the blower that samples the air through IPI.

$(F)$ accounting for scavenging efficiency and radical losses introduced by IPI:

$\mathrm{OH}_{\mathrm{atm}}=\left(S \cdot\left(\mathrm{OHF}_{\mathrm{tot}}-\mathrm{OHF}_{\mathrm{bg}}\right)\right) \cdot F$.

To compare the derived atmospheric $\mathrm{OH}$ concentration with the respective total and background signals and to describe the error in concentration of atmospheric $\mathrm{OH}$ that would have been made without the use of IPI, we apply the same $\mathrm{OH}$ calibration factor to both $\mathrm{OH}$ fluorescence signals, $\mathrm{OHF}_{\mathrm{bg}}$ and $\mathrm{OHF}_{\text {tot }}$, and we refer to them as the background $\mathrm{OH}$ signal $\left(\mathrm{OH}_{\mathrm{bg}}\right)$ and the total $\mathrm{OH}$ signal $\left(\mathrm{OH}_{\mathrm{tot}}\right)$. The units of these variables are therefore molecules $\mathrm{cm}^{-3} \mathrm{OH}$ equivalent and no inference is drawn as to the actual concentration of the interfering species.

As mentioned above, the detection of atmospheric $\mathrm{OH}$ using LIF-FAGE with an additional scavenger was employed following the method described by (Mao et al., 2012). The setup of the $\mathrm{OH}$ scavenger injection and its operation differ between the two LIF-FAGE instruments. The main differences between the two injection systems are the internal 
Table 1. IPI parameters for the three measurement campaigns.

\begin{tabular}{|c|c|c|c|c|}
\hline Campaign & $\begin{array}{l}\text { IPI flow } \\
\text { Residence time }\end{array}$ & Scavenger/flow & $\begin{array}{l}\text { Carrier flow } \\
\text { (Syn. Air) }\end{array}$ & $\begin{array}{l}\text { Measured } \\
\text { scavenging efficiency }\end{array}$ \\
\hline $\begin{array}{l}\text { HUMPPA COPEC } 2010 \\
\& \text { DOMINO } \mathrm{HO}_{\mathrm{x}}\end{array}$ & $\begin{array}{l}280 \mathrm{Lmin}^{-1} \\
\sim 2.5 \mathrm{~ms}\end{array}$ & Propene $/ 20 \mathrm{sccm}$ & $4000 \mathrm{sccm}$ & $>95 \%$ \\
\hline HOPE 2012 & $\begin{array}{l}150 \mathrm{Lmin}^{-1} \\
\sim 4 \mathrm{~ms}\end{array}$ & $\begin{array}{l}\text { Propane } / 5-30 \mathrm{sccm} \\
\text { Propene/2-8 sccm }\end{array}$ & $2700-4300 \mathrm{sccm}$ & $60-95 \%$ \\
\hline
\end{tabular}

shape and the amount of air sampled, leading to differences in radical wall losses and in the scavenging efficiency. The hyperbolic internal shape of IPI (max. cross-section $=35 \mathrm{~mm}$; min. cross-section $=6 \mathrm{~mm}$ ) (Fig. 3) was chosen based on Eisele et al. (1997) to sample air that has little contact with walls and high velocity where the inner diameter is smaller to provide rapid turbulent mixing of atmospheric air and added scavenger. A blower (SCL 20DH from FPZ, Italy) is directly connected to IPI (Fig. 3, label 4) pulling air with a flow rate between 150 and $280 \mathrm{~L} \mathrm{~min}^{-1}$. The flow velocity is monitored using a differential pressure sensor calibrated against a gas metre. An aluminium perforated mesh with square holes is located around the instrument inlet between the nozzle and the connection to the blower sampling the air through IPI (Fig. 3, labels 3 and 4). As the mesh texture is very thin and located above the blower connection, the resistance to the air is strong enough to break the flow pattern that would be strongly pointing towards the direction of the pulling position of the blower, allowing a more homogeneous flow and mixing. The $\mathrm{OH}$ scavenger is injected via eight $0.5 \mathrm{~mm}$ diameter holes (Fig. 3, label 1) into the centre of the flow of air sampled by IPI, $5 \mathrm{~cm}$ above the pinhole of the inlet (Fig. 3, label 2). Assuming plug flow, the estimated residence time of the ambient air in IPI from the injection of the scavenger to the instrument inlet when pulling $150 \mathrm{~L} \mathrm{~min}^{-1}$ of air is $\sim 4 \mathrm{~ms}$. To improve the mixing between the scavenger and the sampled air, the injection happens at the minimum cross-section of IPI, and to achieve a good penetration of the scavenger into the sample flow, the scavenger is injected into IPI with a carrier flow of synthetic air. The carrier air flow ( $\sim 4000 \mathrm{sccm})$ is maintained at all times to keep the conditions in IPI constant. The HORUS inlet samples approximately $7 \mathrm{~L} \mathrm{~min}^{-1}$ of air directly from the centre of the flow.

There are several critical parameters involved in the deployment of this chemical scavenger methodology such as the identity and concentration of scavenger, the IPI sampling flow and therefore the residence time within IPI, and the synthetic air carrier flow. The choice of scavenger and concentration is very important. The $\mathrm{OH}$ scavenger must react quickly with $\mathrm{OH}$ but slowly with other oxidants like ozone and $\mathrm{NO}_{3}$, it should not be toxic and not have a high absorptivity at the laser excitation wavelength. Its concentration should be high enough to affect the removal of a known and substan- tial proportion, $>90 \%$, of atmospheric $\mathrm{OH}$ but should not be in excess to prevent the risk that excess scavenger will react with the internally generated $\mathrm{OH}$. The flow rate of ambient air through IPI must be fast to minimise losses of $\mathrm{HO}_{\mathrm{x}}$ $\left(\mathrm{OH}\right.$ and $\left.\mathrm{HO}_{2}\right)$ onto the walls, and the residence time of $\mathrm{OH}$ within IPI has to be an optimal compromise between being short compared to the atmospheric lifetime of $\mathrm{OH}$ and allowing sufficient time for the scavenger to react. The carrier flow must be high enough to favour efficient mixing between the scavenger and the atmospheric air and to flush the lines when no injection of scavenger takes place. Figure 3 shows the schematic layout of the IPI during the HOPE 2012 campaign. The flow of the scavenger is controlled with a mass flow controller (MFC). After the MFC the scavenger line combines with the carrier gas line where it gets mixed. The mixture then reaches IPI where it is injected into the sampled atmospheric air. In both parts of the injection cycle, i.e. scavenger on and scavenger off, the same amount of air is sampled through IPI and the flow of carrier air is maintained constant. To remove residual scavenger from IPI lines when switching to a period with no injection, the lines are purged with synthetic air at a flow of approximately $5000 \mathrm{sccm}$ for $5 \mathrm{~s}$. The current IPI cycle results in a minimum time resolution for the measurement of atmospheric $\mathrm{OH}$ of one data point over $4 \mathrm{~min}$ consisting of cycles of $2 \mathrm{~min}$ of injection of the $\mathrm{OH}$ scavenger and $2 \mathrm{~min}$ with no injection of the $\mathrm{OH}$ scavenger. Table 1 shows IPI parameters for three measurement campaigns. Details of the three measurement sites are given in the next section. During both HUMPPACOPEC 2010 and DOMINO $\mathrm{HO}_{\mathrm{x}}$ the prototype IPI version was in use. The main difference between the prototype version and the final design in current use, shown in Fig. 3, is the method of scavenger injection. The prototype IPI version injected the scavenger through eight $1 / 16$ inch stainless steel tubes inserted into the centre of the IPI airstream. During these two campaigns the IPI parameters were the same. Propene (Aldrich 295663-330G, 99+\% purity) was used as an $\mathrm{OH}$ scavenger with a flow of $20 \mathrm{sccm}$ and was carried to IPI with $4000 \mathrm{sccm}$ of synthetic air (Westfalen AG). Total IPI sample flow was $\sim 280 \mathrm{~L} \mathrm{~min}^{-1}$ leading to a concentration of propene of $6.4 \times 10^{14}$ molecules $\mathrm{cm}^{-3}$. The residence time between the injection of the scavenger and the instrument inlet was $\sim 2.5 \mathrm{~ms}$, short compared to the lifetime of $\mathrm{OH}$ in those environments (on average $\sim 80 \mathrm{~ms}$; (Nölscher 
et al., 2012; Sinha et al., 2012). Under these conditions, more than $95 \%$ of the atmospheric $\mathrm{OH}$ was scavenged within IPI. During HOPE 2012 the current version of IPI was used (Fig. 3). The current version was designed with a simplified layout to reduce the number of connections and improve ease of use. Two $\mathrm{OH}$ scavengers were tested during the campaign. The main scavenger used was propane (Air Liquide 3.5, $99.95 \%$ purity) applied with an average flow of $17 \mathrm{sccm}$, a carrier flow of synthetic air of $4000 \mathrm{sccm}$ and a sample flow within IPI of $\sim 150 \mathrm{~L} \mathrm{~min}^{-1}$ (propane concentration $\sim 2.5 \times 10^{15}$ molecules $\mathrm{cm}^{-3}$ ). Pulling a smaller flow of atmospheric air through IPI led to a residence time after the injection of the scavenger of $\sim 4 \mathrm{~ms}$, that was still short compared to the average $\mathrm{OH}$ lifetime at the site (on average $\sim 300 \mathrm{~ms}$ ) and that allowed the use of a smaller concentration of scavenger preventing excessive titration of $\mathrm{OH}$ in the low-pressure side of the instrument. With this concentration of propane, the lifetime of $\mathrm{OH}$ was $0.3 \mathrm{~ms}$ and a scavenging efficiency of $\sim 90 \%$ was achieved. Propene was also used for some measurement cycles, for purposes of comparison, every few hours.

\subsection{Measurement sites}

We present measurements from three measurement sites represented by various meteorological and physicochemical characteristics. The HUMPPA-COPEC 2010 (Hyytiälä United Measurements of Photochemistry and Particles in Air-Comprehensive Organic Precursor Emission and Concentration study) campaign took place during the summer of 2010 at the SMEAR II station in Hyytiälä, Finland ( $61^{\circ} 51^{\prime} \mathrm{N}$, $24^{\circ} 17^{\prime} \mathrm{E}, 181 \mathrm{~m}$ a.s.l.) in a boreal forest dominated by Scots Pine (Pinus Silvestris L.). Continuous measurements of several trace gases and meteorological parameters as well as particle size distribution and composition (Junninen et al., 2009) were available. For the first part of the campaign the HORUS instrument measured side-by-side with an OH CIMS operated by the University of Helsinki (Petäjä et al., 2009). During the inter-comparison, the HORUS detection axis (Fig. 1) was located next to a white container where the main body of the CIMS instrument was at a distance of less than a metre from the CIMS inlet and with the sampling position at the same height. Container and instruments were located in a clearing surrounded by a pine forest. More specific information about the meteorology observed during the comparison period are given in Hens et al. (2014). The instrumentation and the meteorological conditions during the campaign are described by Williams et al. (2011). The DOMINO $\mathrm{HO}_{\mathrm{x}}$ campaign took place in November 2010 in El Arenosillo, in southwestern Spain $\left(37^{\circ} 1^{\prime} \mathrm{N}, 6^{\circ} 7^{\prime} \mathrm{W}, 40 \mathrm{~m}\right.$ a.s.l. $)$ at the same site as the DOMINO (Diel Oxidants Mechanisms In relation to Nitrogen Oxide) campaign in 2008 described in Crowley et al. (2011). The site is located in a forested area (Stone pines, Pinus pinea, $5-10 \mathrm{~m}$ in height) close to the South Atlantic Ocean shore and $12 \mathrm{~km}$ from the city of Huelva and associated petrochemical industry. The HOPE 2012 (Hohenpeißenberg Photochemistry Experiment) campaign was conducted during the summer of 2012 at the Meteorological Observatory in Hohenpeissenberg, Bavaria $\left(47^{\circ} 48^{\prime} \mathrm{N}, 11^{\circ} 2^{\prime} \mathrm{E}\right)$. The observatory is operated by the German Weather Service (DWD) and is located at an altitude of $985 \mathrm{~m}$ a.s.l., about $300 \mathrm{~m}$ above the surrounding terrain, which consists mainly of meadows and forests. During the entire campaign the HORUS instrument measured side-by-side with the OH CIMS operated by the German Weather Service (DWD; Berresheim et al., 2000). HORUS detection axis and inlet (Fig. 1) were located on the roof of the building at less than a metre distance from the inlet of the CIMS. The CIMS main body is located in the room below the roof and its inlet is at $\sim 20 \mathrm{~cm}$ height from the ground. Nothing was positioned around the two instruments that were both located on the same corner of the roof opening toward a pine forest. More information about the site and the routine measurements can be found in Handisides et al. (2003).

Both CIMS instruments used during HUMPPA-COPEC 2010 and HOPE 2012 campaigns are based on the instrument described by Berresheim et al. (2000) and in both systems a titration with propane is required in order to measure atmospheric $\mathrm{OH}$. The accuracy of both instruments is determined by the accuracy of the calibration system that includes both instrumental uncertainty and interferences caused by ambient parameters. The accuracy of the CIMS operated by the University of Helsinki is $32 \%$ ( $1 \sigma$ ) (Hens et al., 2014) and the accuracy of the DWD-CIMS is $30 \%(1 \sigma)$. The precision of the instruments considered counting statistics, potential wind and chemical interferences caused by NO, $\mathrm{NO}_{2}, \mathrm{CO}$ and hydrocarbons. The precision of the DWDCIMS instrument is $26 \%(1 \sigma, 30 \mathrm{~s}$ data) while the precision for the CIMS operated by the University of Helsinki is based on $30 \mathrm{~min}$ average data and their variability, calculated for every single point; for a typical $\mathrm{OH}$ concentration of $1 \times 10^{6}$ molecules $\mathrm{cm}^{-3}$ the precision was $5 \times$ $10^{5}$ molecules $\mathrm{cm}^{-3}$ (Hens et al., 2014).

\section{Results and discussion}

\subsection{IPI characterisation}

The addition of IPI to HORUS has a significant effect on the performance of the instrument with respect to losses of radicals in the inlet system. To account for the perturbation of the atmospheric $\mathrm{OH}$ measurement caused by the use of IPI, a number of tests were completed to assess the effects of changing instrumental parameters. Total radical loss on the IPI system, the variation of this loss with the atmospheric air sampled and with scavenger carrier flow, and the efficiency of $\mathrm{OH}$ removal by the scavenger were tested during the different campaigns in which HORUS was in use with IPI. The tests described below were performed during the HOPE 2012 campaign with the current version of IPI (Fig. 3). Titrations 

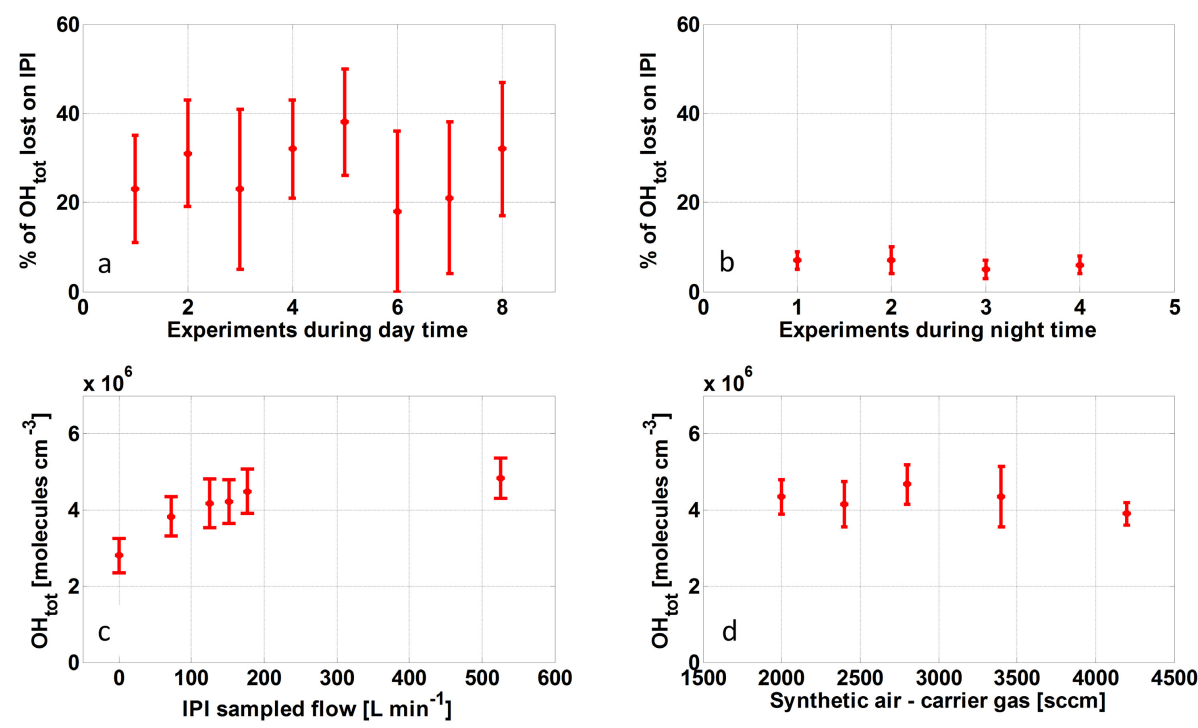

Figure 4. The loss of the total $\mathrm{OH}$ signal observed by measuring with and without IPI mounted on top of the inlet for day (a) and night (b) time; total OH signal measured while varying the sample flow through IPI (c); total OH signal measured with a constant IPI sampling flow of $\sim 150 \mathrm{~L} \mathrm{~min}^{-1}$ and adding between 2000 and $4300 \mathrm{sccm}$ of carrier gas flow (d). The results shown here were obtained during the HOPE 2012 campaign.

of atmospheric $\mathrm{OH}$ within IPI using different scavengers were completed with a stable source of $\mathrm{OH}$ radicals. The total radical loss in IPI was performed using ambient air as no artificial $\mathrm{OH}$ source is currently available due to the very high flow rates of zero air required. These tests were repeated and monitored through the entire campaign to obtain robust results. Tests were performed during daytime, between 10:00 and 16:00 LT, and night time after 20:00 to distinguish the effect of IPI with high radical load, i.e. during the day, from situations where interferences might dominate the total signal, i.e. during the night.

Figure $4 \mathrm{a}$ and $\mathrm{b}$ show the average results of the radical loss tests checked by routinely measuring with and without IPI mounted on the inlet, conducted multiple times during the day and the night, respectively, with a sampled flow of $\sim 150 \mathrm{~L} \mathrm{~min}^{-1}$ and a carrier gas of $4000 \mathrm{sccm}$. The average total $\mathrm{OH}$ signal loss was $27 \%$ during the day and $7 \%$ during the night. The error bars for every single point represent the variability of the data $(1 \sigma)$ during a single test. As the measurement characterising the losses of the total $\mathrm{OH}$ signal were completed during daytime when the ratio of atmospheric $\mathrm{OH}$ to background $\mathrm{OH}$ was highest, most of the variability is caused by the ambient variability of $\mathrm{OH}$. Figure $4 \mathrm{c}$ shows the loss of the total $\mathrm{OH}$ signal while changing sample flow through IPI with no carrier air and scavenger. The minimum loss, $20 \%$, occurs at sample flows larger than $500 \mathrm{~L} \mathrm{~min}^{-1}$ while at the flow in use during the campaign, $150 \mathrm{~L} \mathrm{~min}^{-1}$, the loss observed was $\sim 30 \%$. Figure $4 \mathrm{~d}$ shows the losses of the total OH signal in IPI with the variation of the additional carrier flow used to mix the scavenger with the sampled atmospheric air while sampling $150 \mathrm{~L} \mathrm{~min}^{-1}$ of air. No dependency on the carrier flow rate between 1000 and $5000 \mathrm{sccm}$ and no additional loss of $\mathrm{OH}$ compared to the loss due to the sampling of $150 \mathrm{~L} \mathrm{~min}^{-1}$ of air were observed, indicating that the major cause of losses is due to contact with surfaces. The measured losses during daytime, on average $27 \%$, are the losses of the total $\mathrm{OH}$ signal and therefore the sum of the losses of atmospheric $\mathrm{OH}$ and losses of the species causing the background $\mathrm{OH}$. During night time an average loss of $7 \%$ was measured from the total $\mathrm{OH}$ signal; since the atmospheric $\mathrm{OH}$ signal was below the limit of detection of the instrument $\left(4 \times 10^{5}\right.$ molecules $\mathrm{cm}^{-3}, 4$ min data) during the tests described, the loss is assumed to be entirely due to the species causing the background $\mathrm{OH}\left(L_{\mathrm{bg}}\right)$. The loss of atmospheric $\mathrm{OH}\left(L_{\mathrm{OH}}\right)$ is equal to the atmospheric $\mathrm{OH}$ signal measured with IPI mounted on the top of the inlet $\left(\mathrm{OH}_{\mathrm{atm}}^{\mathrm{IPI}}\right)$ divided by the atmospheric $\mathrm{OH}$ signal measured without IPI mounted on the top of the inlet $\left(\mathrm{OH}_{\mathrm{atm}}^{\mathrm{NoIPI}}\right)$ :

$L_{\mathrm{OH}}=\frac{\mathrm{OH}_{\mathrm{atm}}^{\mathrm{IPI}}}{\mathrm{OH}_{\mathrm{atm}}^{\mathrm{NoIPI}}}$.

The value of atmospheric $\mathrm{OH}$ without IPI mounted on the top of the inlet is impossible to measure but, by assuming that $L_{\text {bg }}$ is constant, the loss on the atmospheric $\mathrm{OH}$ signal can be calculated using

$L_{\mathrm{OH}}=\frac{\left(\mathrm{OH}_{\mathrm{tot}}^{\mathrm{IPI}}-\mathrm{OH}_{\mathrm{bg}}^{\mathrm{IPI}}\right)}{\mathrm{OH}_{\mathrm{tot}}^{\mathrm{NoIPI}}-\left(\frac{\mathrm{OH}_{\mathrm{bg}}^{\mathrm{IPI}}}{L_{\mathrm{bg}}}\right)}$.

The $\mathrm{OH}_{\mathrm{tot}}^{\mathrm{IPI}}$ and $\mathrm{OH}_{\mathrm{bg}}^{\mathrm{IPI}}$ are the total $\mathrm{OH}$ signal and the background $\mathrm{OH}$ signal, respectively, measured by the instrument 


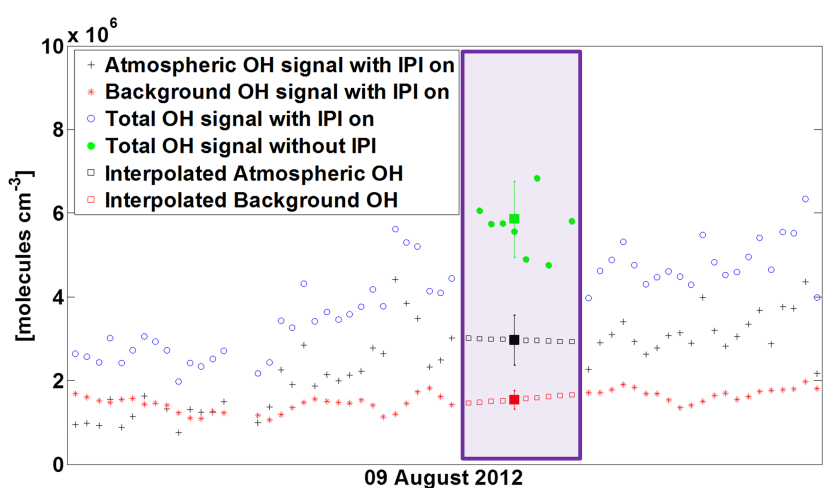

Figure 5. Example of an IPI on and off test during the HOPE 2012 campaign. The shaded area represents the test period when IPI was removed from the top of the inlet of the LIF-FAGE instrument. The green circles represent the total $\mathrm{OH}$ signal measured without IPI. Black crosses, red stars and blue circles represent, respectively, the atmospheric, the background and the total $\mathrm{OH}$ measured with IPI. The filled square markers show the average of the total $\mathrm{OH}$ signal measured without IPI (green) and the average of the interpolated signal (open squared markers) before and after the test period for the atmospheric (red) and background (black) OH. The error bars represent the $1 \sigma$ standard deviation. By using Eq. (5), this test results in an $\mathrm{OH}$ loss within IPI of $32 \%$.

with IPI mounted on the inlet and therefore affected by losses, and their difference is the atmospheric $\mathrm{OH}$ affected by losses, $\mathrm{OH}_{\mathrm{atm}}^{\mathrm{IPI}}$. The $\mathrm{OH}_{\mathrm{tot}}^{\mathrm{NoIPI}}$ is the total $\mathrm{OH}$ signal measured during the tests without IPI on top of the inlet and therefore not affected by losses. Figure 5 shows an example of a test during which IPI was physically removed from the top of the instrument inlet (shaded area). IPI can be removed easily in less than 2 min and, on average, we measured without IPI during one period for $30 \mathrm{~min}$ and measurements were repeated routinely every 4 days during the HOPE 2012 campaign. Referring to Eq. (5), for one IPI on and off test, the numerator (the atmospheric $\mathrm{OH}$ signal affected by losses) is the result of the interpolation of the measured atmospheric $\mathrm{OH}$ signal $12 \mathrm{~min}$ before and after the removal of IPI. In the denominator, the total $\mathrm{OH}$ measured when IPI was not on the inlet is the average of the signal measured when IPI was not on the top of the inlet. The background $\mathrm{OH}$ measured with IPI is obtained from the interpolation of the measured background $\mathrm{OH}$ signal $12 \mathrm{~min}$ before and after the removal of IPI and is divided by the loss of the background $\mathrm{OH}$ measured during night time tests. The average value obtained for the loss of the atmospheric $\mathrm{OH}$ is $34 \%$ and the data have been corrected accordingly. The variability observed for the average $\mathrm{L}_{\mathrm{OH}}$ value, $\pm 15 \%(1 \sigma)$, was taken into account for the accuracy of the HORUS instrument after the addition of IPI. The accuracy of HORUS was $34 \%(2 \sigma)$ and the accuracy of IPI-HORUS becomes $42 \%(2 \sigma)$. The detection limit of IPI-HORUS is obtained from the statistical significance of the difference between the total $\mathrm{OH}$ sig-

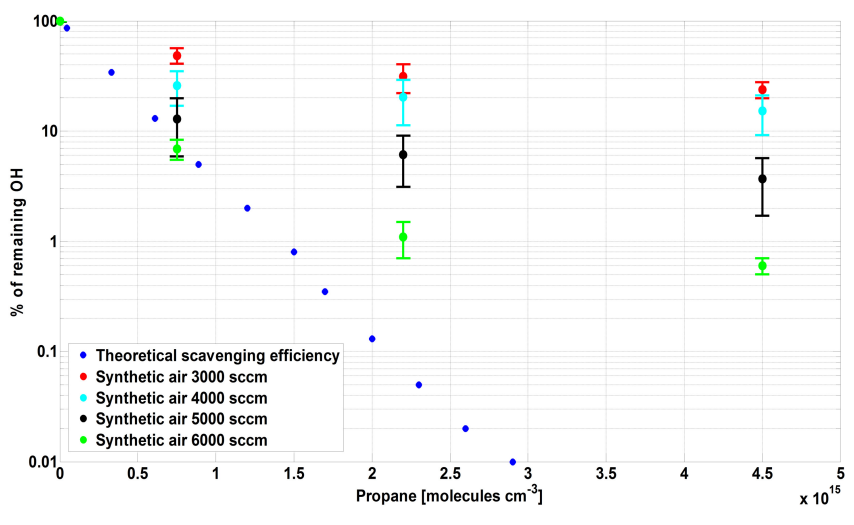

Figure 6. Comparison between the calculated theoretical scavenging efficiency of propane and the measured scavenging efficiency at four different synthetic air carrier gas flows for three different concentrations of propane.

nal and the background $\mathrm{OH}$ signal determined by $t$-test $(1 \sigma)$ and decreased from $9 \times 10^{5}$ molecules $\mathrm{cm}^{-3}$ (4 min data) for the HUMPPA-COPEC 2010 and DOMINO $\mathrm{HO}_{\mathrm{x}}$ campaigns to $4 \times 10^{5}$ molecules $\mathrm{cm}^{-3}$ (4 min data) for the HOPE 2012 campaign due to higher laser power.

To optimise the $\mathrm{OH}$ scavenging efficiency, several titrations of $\mathrm{OH}$ were conducted during the campaign with various operational conditions to examine the stability of the instrument and the reproducibility of the background subtraction. The optimisation of the scavenger concentration is also important due to its potential to remove part of the internally produced $\mathrm{OH}$ in the low-pressure region of the instrument, which would result in the overestimation of the atmospheric $\mathrm{OH}$ concentration. The titration experiments were performed by producing a constant above ambient concentration of $\mathrm{OH}$ of about $\sim 10^{9}$ molecules $\mathrm{cm}^{-3}$ in front of IPI using a mercury lamp and ambient air and by varying the concentration of the scavenger to measure the efficiency in the removal of the $\mathrm{OH}$ molecules within IPI. By sending a concentration of $2.5 \times 10^{15}$ molecules $\mathrm{cm}^{-3}$ of propane, $90 \%$ of the initial $\mathrm{OH}$ was removed. We calculated the theoretical scavenging efficiency for each $\mathrm{OH}$ scavenger deployed during the campaign based on the residence time in IPI after the injection of the scavenger $(\sim 4 \mathrm{~ms})$ and inside the instrument in the low-pressure region $(\sim 2.5 \mathrm{~ms})$, and on the rate coefficients for the reactions between the respective scavenger and $\mathrm{OH}$ at ambient and low pressure ( $2350 \mathrm{~Pa})$ (Sander et al., 2011). Figure 6 shows, in blue, the theoretical $\mathrm{OH}$ titration efficiency of scavenger depending on the scavenger concentration for the case of propane. Also shown are experimental titrations performed with propane, at different carrier gas flow rates. The carrier gas flow does not have a significant impact on the dilution of the scavenger as it represents a minor percentage of the total flow sampled by IPI. What it does influence is the mixing of the scavenger with the atmospheric air, and thus the scavenging efficiency. 


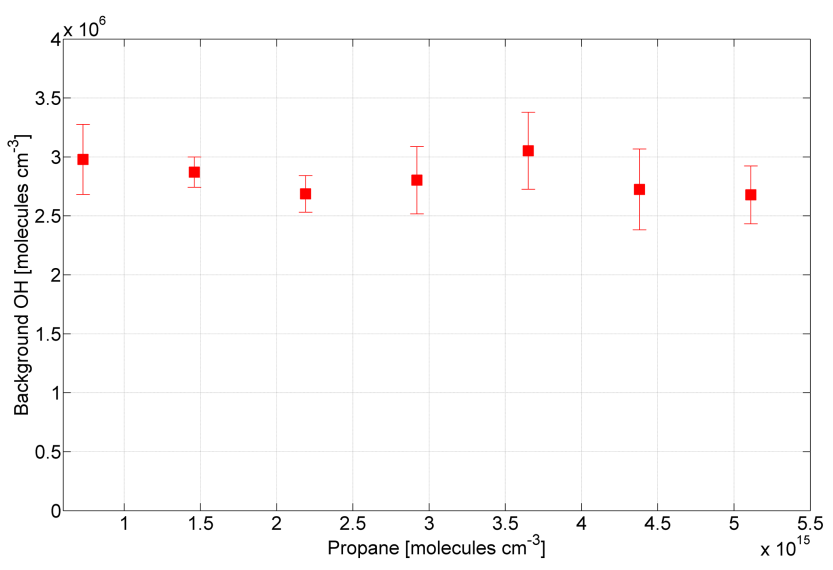

Figure 7. Background $\mathrm{OH}$ observed at a constant atmospheric $\mathrm{OH}$ concentration when injecting different concentrations of propane.

The experimental data show a deviation from the calculated curve. At higher carrier gas flows the experimental data are closer to the model results. The deviation from the modelled data may be related to incomplete mixing between the sampled atmospheric air and the $\mathrm{OH}$ scavenger; by increasing the carrier gas flow, and therefore improving the mixing, we would expect to approach the theoretical titration efficiency. The setup during the HOPE 2012 campaign allowed us to have a stable carrier flow only for flows below 4500 sccm. At higher values, the MFC controlling the carrier flow showed high sensitivity to even small temperature-driven changes in the backing pressure of the supply gas. Therefore, the flow was kept stable at $4000 \mathrm{sccm}$, even though this is suboptimal with respect to mixing, and the amount of $\mathrm{OH}$ scavenged was checked regularly by repeated titrations. The calculated theoretical scavenging efficiency also predicts the amount of $\mathrm{OH}$ we would be removing in the low-pressure region of the instrument at a certain concentration of scavenger. During the HOPE 2012 campaign the concentration of propane in use was small enough to allow the removal of less than $2 \%$ of the $\mathrm{OH}$ in the low-pressure region. As the calculation assumes perfect mixing, the amount of internal scavenging was tested by changing the propane flow from 5 to $35 \mathrm{sccm}$ whilst keeping a constant and small concentration of atmospheric $\mathrm{OH}$ (night time period). Figure 7 shows a negligible variation in the background $\mathrm{OH}$ signal, well within the precision of the instrument, even when increasing the propane concentration by a factor of 7 . Therefore, an impact from internal $\mathrm{OH}$ scavenging on the determination of the atmospheric $\mathrm{OH}$ can be excluded. The prototype IPI version was used during the HUMPPA-COPEC 2010 and the DOMINO $\mathrm{HO}_{\mathrm{x}}$ campaigns and the instrument was run with the same parameters in both campaigns. Similar tests to the ones previously described were performed during HUMPPA-COPEC 2010 but as shown in Fig. 8, most of the total $\mathrm{OH}$ signal measured by the instrument was due to the background $\mathrm{OH}$ both during day and night time. In this situation it is difficult to account for possible losses of the $\mathrm{OH}$ radical because its contribution to the total signal is too small. Total radical loss tests were performed but the results were not as unambiguous as for the HOPE 2012 campaign case; sometimes a small $\mathrm{OH}$ loss was observed on IPI but during most of the tests there was no clear indication of $\mathrm{OH}$ loss although any $\mathrm{OH}$ losses would likely be masked by the high background signal. Propene was originally selected as scavenger because of its high reaction rate with $\mathrm{OH}$, allowing rapid $\mathrm{OH}$ scavenging even at low concentration. However, propene is known to form $\mathrm{OH}$ radicals after reaction with ozone with a yield of 0.34 (Atkinson et al., 2006). Hence, by mixing high concentrations of propene with the ambient air we expect formation of additional $\mathrm{OH}$ radicals. During HUMPPA-COPEC 2010 the residence time in IPI after the injection of the scavenger was $\sim 2.5 \mathrm{~ms}$ such that the concentration of ambient ozone and propene, even if reacting quickly with $\mathrm{OH}$, can be assumed to be constant. The steady-state concentration of $\mathrm{OH}$ with the concentration of propene within IPI $\left(\sim 6 \times 10^{14}\right.$ molecules $\left.\mathrm{cm}^{-3}\right)$ is reached after $0.5 \mathrm{~ms}$, therefore the average steady-state $\mathrm{OH}$ concentration produced by propene can be calculated by taking into account the average ambient ozone concentration during the campaign, the rate coefficient between ozone and propene, $k_{1}=1 \times 10^{-17} \mathrm{~cm}^{3}$ molecules ${ }^{-1} \mathrm{~s}^{-1}$ at $298 \mathrm{~K}$, the $\mathrm{OH}$ yield, $Y=0.34$, and the rate coefficient between propene and $\mathrm{OH}$ at $1013 \mathrm{hPa}$ and $298 \mathrm{~K}, k_{2}=2.9 \times 10^{-11} \mathrm{~cm}^{3}$ molecules $^{-1} \mathrm{~s}^{-1}$ (Atkinson et al., 2006):

$[\mathrm{OH}]=\frac{\left[\mathrm{O}_{3}\right] \cdot k_{1} \cdot Y}{k_{2}}$.

This calculation represents an upper limit for the possible production of $\mathrm{OH}$ during the injection of propene as scavenger as it does not consider any physical losses for $\mathrm{OH}$ or ozone on IPI and also assumes perfect mixing between propene and ambient air. The $\mathrm{OH}$ concentration produced during the injection of propene depends only on the ozone concentration. The peak mixing ratio of ozone during the HUMPPA-COPEC 2010 campaign was $80 \mathrm{ppbv}$, which would result in a maximum $\mathrm{OH}$ concentration of $2.3 \times 10^{5}$ molecules $\mathrm{cm}^{-3}$. For the average ozone value of $44 \mathrm{ppbv}$ the steady-state $\mathrm{OH}$ concentration would be $1.2 \times$ $10^{5}$ molecules $\mathrm{cm}^{-3}$. This additional $\mathrm{OH}$ would cause an underestimation of the atmospheric $\mathrm{OH}$ calculated after subtraction of the background $\mathrm{OH}$ signal from the total $\mathrm{OH}$ measured by the instrument and would increase the uncertainty on our OH measurement. During the HOPE 2012 campaign we performed tests using propene and propane as $\mathrm{OH}$ scavengers intermittently at an ambient concentration of ozone of $\sim 40 \mathrm{ppbv}$ to estimate the production of $\mathrm{OH}$ due to propene ozonolysis. Figure 9 shows that there is no significant difference between the atmospheric $\mathrm{OH}$ concentration determined with the use of propane and the $\mathrm{OH}$ concentration determined using propene as the average value was 

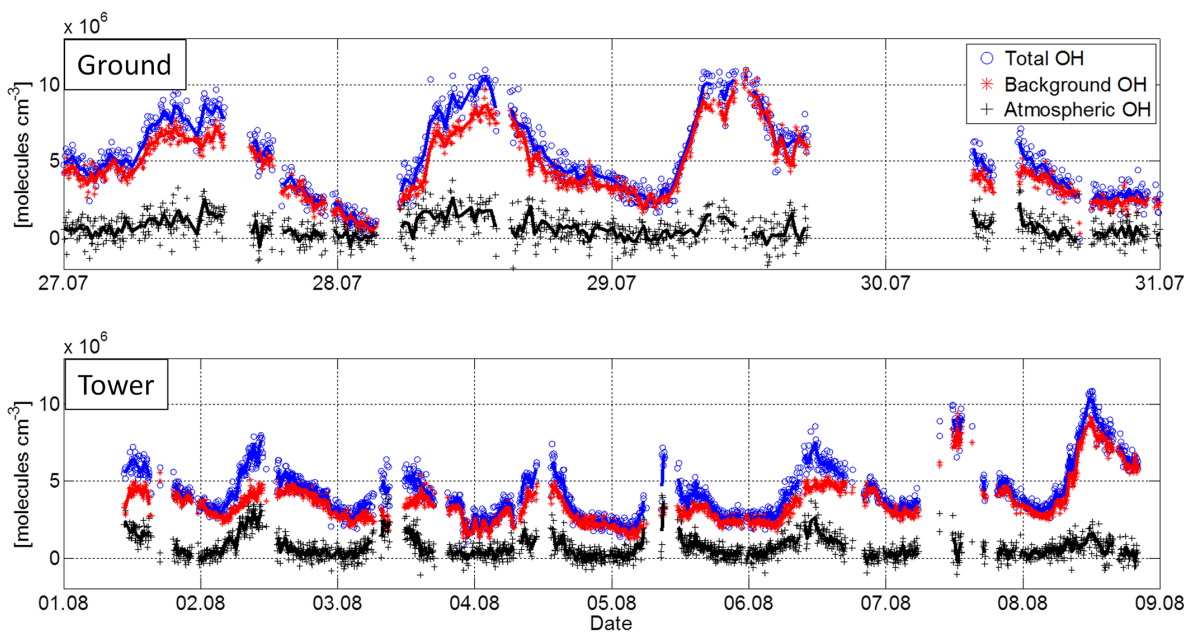

Figure 8. OH signals measured by HORUS during HUMPPA-COPEC 2010 campaign. The blue circles represent the total OH signal measured by the instrument in the absence of an $\mathrm{OH}$ scavenger. The red stars represent the background $\mathrm{OH}$ measured during the injection of an $\mathrm{OH}$ scavenger. The black crosses represent the atmospheric $\mathrm{OH}$ obtained by difference between total $\mathrm{OH}$ and background $\mathrm{OH}$. The solid lines are $30 \mathrm{~min}$ averages. The top panel shows the data collected on the ground and the bottom panel shows the data collected on the tower. Time is in $\mathrm{UTC}+2$.

$(0.5 \pm 1.5) \times 10^{5}$ molecules $\mathrm{cm}^{-3}(1 \sigma)$. This value is lower than the theoretical one calculated for the same concentration of ozone, indicating additional loss processes. Because the ambient concentrations of ozone and the propene concentration in use during the tests performed in HOPE 2012 and HUMPPA-COPEC 2010 were comparable, assuming similar mixing within the two versions of IPI, we can expect similar $\mathrm{OH}$ production of $0.5 \times 10^{5}$ molecules $\mathrm{cm}^{-3}$ during the HUMPPA-COPEC 2010 campaign. The value is below the precision of the $\mathrm{OH}$ measurement and therefore the data were not corrected for this effect.

To summarise, IPI prototype was in use during the HUMPPA-COPEC 2010 and DOMINO HOx campaigns. No correction factor, $F$, from Eq. (3) was applied for radical losses for the atmospheric $\mathrm{OH}$ data collected during those campaigns as no clear value for losses of atmospheric $\mathrm{OH}$ in IPI was obtained. As propene was used as scavenger aiming at the removal of more than $95 \%$ of the atmospheric $\mathrm{OH}$ and no additional $\mathrm{OH}$ was produced while using it (Fig. 9) also no correction for the scavenger efficiency was applied. During HOPE 2012 the correction factor includes the $34 \%$ average value of losses of atmospheric $\mathrm{OH}$ in IPI walls and a point-by-point correction for the scavenger efficiency. The scavenger efficiency is based on the scavenger used and its concentrations and it is obtained from the titration tests performed regularly during the campaign.

\subsection{Atmospheric measurements using IPI}

Figure 8 shows the signals resulting from the first use of $\mathrm{HO}$ RUS with IPI during the HUMPPA-COPEC 2010 campaign. The top time series highlights the period in which the instrument was on the ground next to a CIMS measuring $\mathrm{OH}$ and

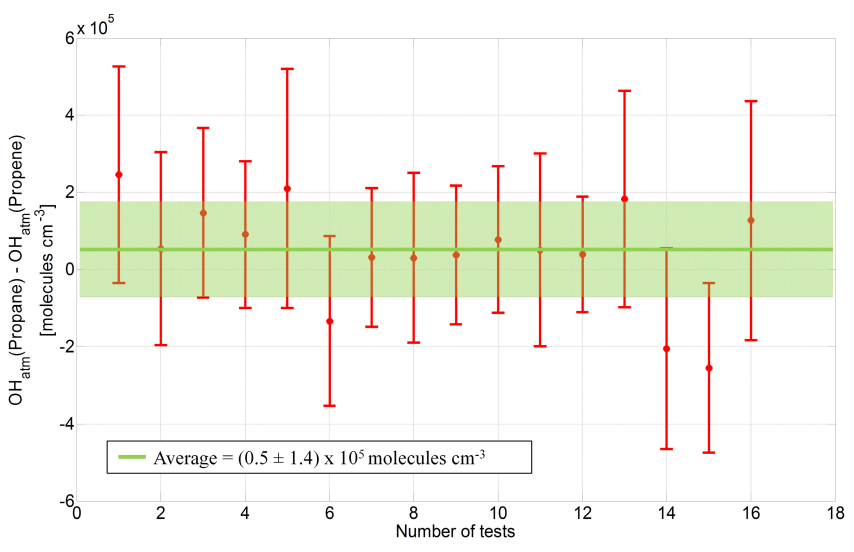

Figure 9. Difference between the atmospheric $\mathrm{OH}$ concentration determined with the use of propane as scavenger and the atmospheric $\mathrm{OH}$ concentration determined with the use of propene. The points are $1 \mathrm{~h}$ averages. The green line is the average value of $0.5 \times 10^{5}$ molecules $\mathrm{cm}^{-3}$ and the shaded area is the $1 \sigma$ range.

$\mathrm{H}_{2} \mathrm{SO}_{4}$ (Petäjä et al., 2009), while the lower series shows the period in which the instrument was operated on a $24 \mathrm{~m}$ tower just above the forest canopy. During the day, within the partially shaded forest canopy, the background $\mathrm{OH}$ signal reaches up to $1 \times 10^{7}$ molecules $\mathrm{cm}^{-3}$ contributing $80 \%$ to the total signal. On the tower the maximum value reached by the background $\mathrm{OH}$ signal is $7 \times 10^{6}$ molecules $\mathrm{cm}^{-3}$ contributing up to $60 \%$ to the total $\mathrm{OH}$ signal measured on the majority of days. During night time the background $\mathrm{OH}$ concentration falls below $4 \times 10^{6}$ molecules $\mathrm{cm}^{-3}$, but as the atmospheric $\mathrm{OH}$ concentration is small the fraction is almost $100 \%$. A side-by-side comparison with the CIMS instrument 


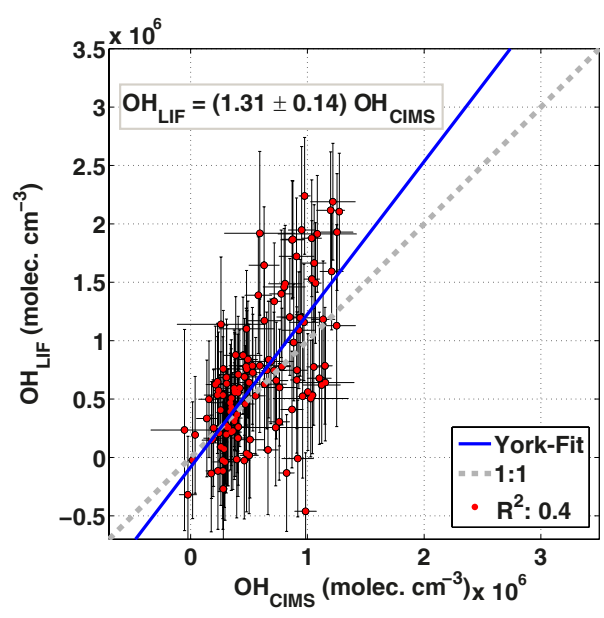

Figure 10. Comparison of OH radical measurements by HORUS and CIMS instruments during the HUMPPA-COPEC 2010 campaign based on $30 \mathrm{~min}$ averages. Linear regression following the method of York et al. (2004) yields a slope of $1.31 \pm 0.14$ and an insignificant offset of $(-8 \pm 9) \times 10^{4}$ molecules $\mathrm{cm}^{-3}$. The precision on the atmospheric $\mathrm{OH}$ for both CIMS and LIF-FAGE has been estimated based on the variability of the atmospheric $\mathrm{OH}$ signal within 2 hours and therefore represents an upper limit precision since it is partially influenced by the atmospheric variability of the ambient OH (Hens et al., 2014).

was performed for the first part of the campaign while both instruments were on the ground. Figure 10 shows the relationship between the atmospheric OH measured by the LIF and the $\mathrm{OH}$ measured by the CIMS. The correlation coefficient, $R^{2}=0.4$, is affected by the large scatter of the LIF OH data due to low laser power, a rapidly ageing detector, and the large contribution that the background signal makes to the total signal. Overall, the LIF measures higher $\mathrm{OH}$ values with a comparison slope of 1.30 , however the difference is within the accuracy of the instruments (HORUS: $42 \%, 2 \sigma$; CIMS: $64 \%, 2 \sigma)$ (Hens et al., 2014).

During the DOMINO $\mathrm{HO}_{\mathrm{x}}$ campaign in November 2010 (Fig. 11), the background $\mathrm{OH}$ signal was always below $4 \times 10^{6}$ molecules $\mathrm{cm}^{-3}$ contributing about $50 \%$ to the total $\mathrm{OH}$ measured during the day and $100 \%$ during the night. During the 3 days of measurements, two different wind sectors were sampled: air travelling from the city of Huelva and air travelling over the continent. There appears to be little difference between the contributions of the background signal in either of these wind sectors.

Figure 12 shows the $\mathrm{OH}$ signals measured by the LIF during the HOPE 2012 campaign for a day at the beginning of the campaign (Fig. 12a) and a day at the end of the campaign (Fig. 12b). The data shown are representative of the concentrations generally observed during the campaign period. During the whole campaign the HORUS LIF was measuring side-by-side with a CIMS instrument (DWD-CIMS). The agreement between the two measurements of atmospheric

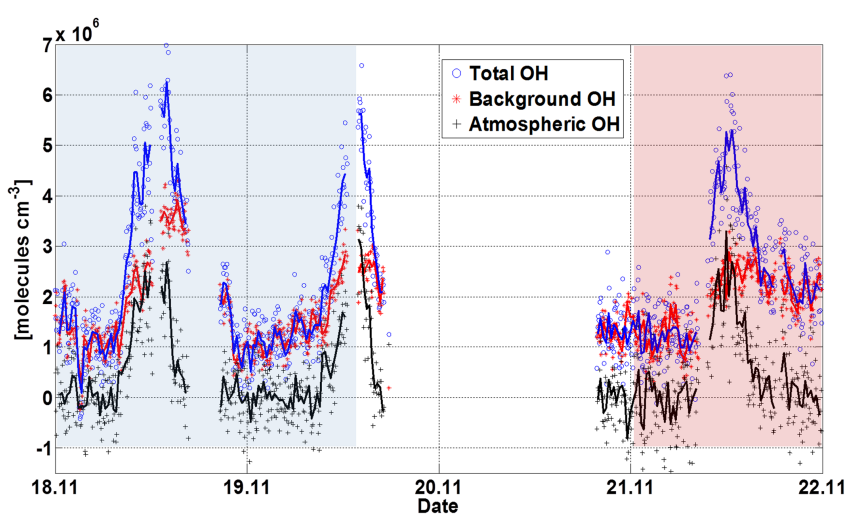

Figure 11. OH signals measured by HORUS during the DOMINO $\mathrm{HO}_{\mathrm{x}}$ campaign. The blue circles represent the total $\mathrm{OH}$ signal measured in the absence of an $\mathrm{OH}$ scavenger. The red stars represent the background $\mathrm{OH}$ measured during the injection of an $\mathrm{OH}$ scavenger. The black crosses represent the atmospheric $\mathrm{OH}$ obtained by difference between total $\mathrm{OH}$ and background $\mathrm{OH}$. The solid lines are $30 \mathrm{~min}$ averages. The two shaded areas represent the two prevailing wind directions: the blue area during wind from the continental sector and the red area from the Huelva sector. Time is in UTC.

$\mathrm{OH}$ is good (Fig. 13), with a correlation coefficient for the entire data set of $R^{2}=0.81$, a slope of 0.94 and an offset of $4.5 \times 10^{5}$ molecules $\mathrm{cm}^{-3}$. The offset is partly caused by night time atmospheric $\mathrm{OH}$ observed during several nights by the HORUS instrument. When removing the night time data (between 18:30 and 07:30 UTC) from the correlation plot (Fig. 13) it is still possible to observe a linearity in the data set with a correlation coefficient of $R^{2}=0.70$, a slope of 0.90 and an offset of $3 \times 10^{5}$ molecules $\mathrm{cm}^{-3}$. This offset indicates that on average the HORUS instrument measured higher values of atmospheric $\mathrm{OH}$ radicals compared to the CIMS. No significant offset was observed during the HUMPPA-COPEC 2010 campaign, indicating that the discrepancy could originate from the DWD-CIMS instrument. The night time $\mathrm{OH}$ measured by HORUS is not constant: during some nights the two instruments agree, both showing an $\mathrm{OH}$ signal scattering around zero. Propane was used as scavenger under the same instrumental conditions during periods when HORUS did and did not measure zero atmospheric $\mathrm{OH}$. No correlation between the atmospheric $\mathrm{OH}$ measured during night and the background $\mathrm{OH}$ was observed. In addition, preliminary budget calculations suggest that as the $\mathrm{OH}$ reactivity measured was very small during night time, the production of $\mathrm{OH}$ via recycling of $\mathrm{HO}_{2}$ through $\mathrm{NO}$ and from ozonolysis of VOCs could lead to a concentration of $\sim 3 \times 10^{5}$ molecules $\mathrm{cm}^{-3}$, similar to what is detected by HORUS. However, it is still unclear where the offset is generated from and further investigations are needed. The background $\mathrm{OH}$ signal during the campaign ranged from a minimum of $1 \times 10^{6}$ to a maximum of $7 \times 10^{6}$ molecules $\mathrm{cm}^{-3}$ on 2 days during which forest cutting was performed near the site but it was, for the most part, below $4 \times 10^{6}$ molecules $\mathrm{cm}^{-3}$. The background signal 

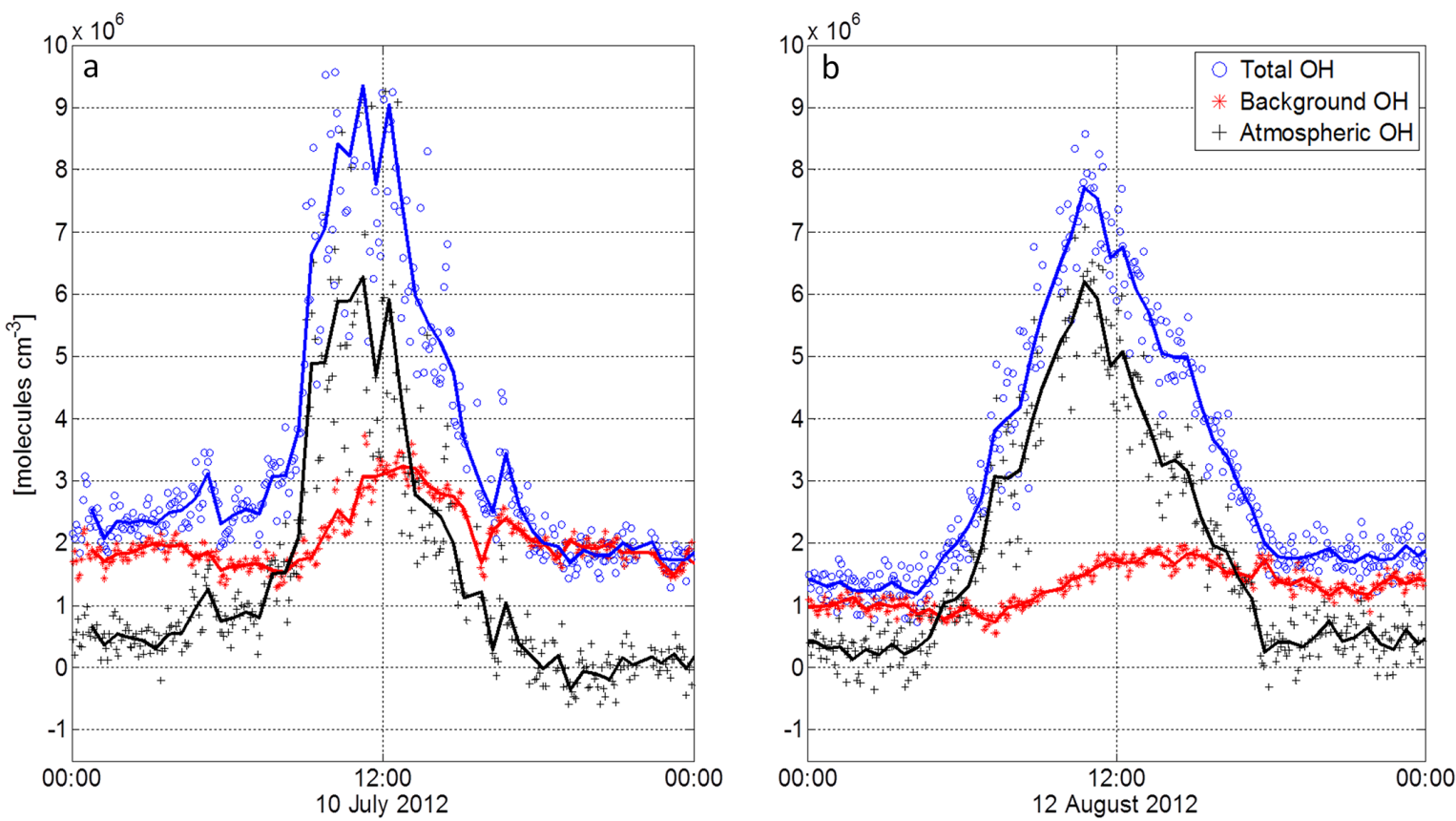

Figure 12. OH signals measured by HORUS during the HOPE 2012 campaign for a day at the beginning (a) and at the end (b) of the campaign. The blue circles represent the total $\mathrm{OH}$ signal measured in the absence of an $\mathrm{OH}$ scavenger. The red stars represent the background $\mathrm{OH}$ measured during the injection of an $\mathrm{OH}$ scavenger. The black crosses represent the atmospheric $\mathrm{OH}$ obtained by difference between total $\mathrm{OH}$ and background $\mathrm{OH}$. The solid lines are 30 min averages. Time is in UTC.

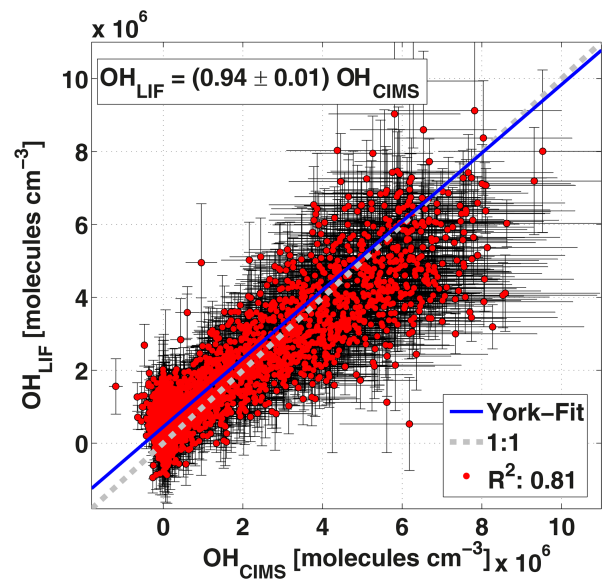

Figure 13. Comparison of $\mathrm{OH}$ radical measurements by HORUS LIF and DWD-CIMS instruments during the HOPE 2012 campaign based on $4 \mathrm{~min}$ average data. The linear regression follows the method of York et al. (2004), and yields a slope of $0.94 \pm 0.01$ and an offset of $(4.5 \pm 0.06) \times 10^{5}$ molecules $\mathrm{cm}^{-3}$.

contributed between 20 and $40 \%$ to the total $\mathrm{OH}$ signal during daytime and up to $100 \%$ of the total $\mathrm{OH}$ signal during night time.

The three measurement campaigns show large differences in the background $\mathrm{OH}$ signal and its contribution to the total $\mathrm{OH}$ signal measured by HORUS. The smallest contri- bution to the total $\mathrm{OH}$ was observed during HOPE 2012, where the total $\mathrm{OH}$ measured by HORUS during daytime for most of the days would have agreed with the DWDCIMS instrument within the accuracy of the instruments even without the chemical scavenger method. At the other extreme lies the HUMPPA-COPEC 2010 campaign where the background $\mathrm{OH}$ signal within the forest canopy reaches $1 \times 10^{7}$ molecules $\mathrm{cm}^{-3}$ on top of a smaller atmospheric $\mathrm{OH}$ concentration, often below $2 \times 10^{6}$ molecules $\mathrm{cm}^{-3}$. The relative contribution of the background signal is lower for the measurement period on the tower where the atmospheric concentration of $\mathrm{OH}$ is higher due to larger values of $j(\mathrm{O})^{1} \mathrm{D}$ compared to the location below the canopy (Hens et al., 2014). One difference between the conditions in HOPE 2012 and HUMPPA-COPEC 2010 is the measured OH reactivity, which was relatively high during HUMPPA-COPEC 2010, on average $12 \mathrm{~s}^{-1}$ with peaks of over $40 \mathrm{~s}^{-1}$ (Nölscher et al., 2012) and often below the detection limit during HOPE 2012 (on average $3.5 \pm 2 \mathrm{~s}^{-1}$ ). The average concentration of measured BVOCs (isoprene, $(-) /(+) \alpha$-pinene, $(-) /(+) \beta$ pinene, 3-carene, myrcene, sabinene) is similar for the two campaigns; approximately 300 pptv (Hens et al., 2014) with HUMPPA-COPEC 2010 showing higher concentrations of monoterpenes and large emissions rates of sesquiterpenes (Yassaa et al., 2012) compared to the HOPE 2012 campaign in addition to unexplained $\mathrm{OH}$ reactivity (Nölscher et al., 2012) that indicates the presence of unmeasured VOCs (Di Carlo et al., 2004). The interpretation of the DOMINO 
$\mathrm{HO}_{\mathrm{x}}$ data is more complex; this campaign was at the same site of the DOMINO 2008 campaign but only a few trace gases (ozone and $\mathrm{NO}_{\mathrm{x}}$ ) and some meteorological parameters were measured in 2010. During the DOMINO 2008 campaign HORUS was in use without the injection of a chemical scavenger and, due to the observation of an interfering signal during DOMINO $\mathrm{HO}_{\mathrm{x}}$, the $\mathrm{OH}$ concentration measured previously should be considered an upper limit. Because DOMINO $\mathrm{HO}_{\mathrm{x}}$ was performed during the same month as the DOMINO 2008 campaign and no sign of differences in local pollution (street work, new buildings next to the site, etc.) or unusual weather was observed, we expect a similar amount of background $\mathrm{OH}$, i.e. about $50 \%$ of the total $\mathrm{OH}$ measured in DOMINO $\mathrm{HO}_{\mathrm{x}}$, for the DOMINO 2008 campaign. During DOMINO 2008 relatively high OH reactivity was measured, with an average of approximately $18 \mathrm{~s}^{-1}$ (Sinha et al., 2012), as well as low concentrations of measured BVOCs (mainly isoprene, eucalyptol and $(-) /(+)$ camphor) consistent with low emissions from vegetation during fall, in the range of $50 \mathrm{pptv}$ (Song et al., 2011) with isoprene being the most abundant BVOC measured. The concentration of anthropogenic VOCs (AVOCs) measured was on average 400 pptv consisting mainly of benzene and toluene, although only a fraction of the AVOCs was quantified on this campaign. The highest reactivity was found for air masses arriving from the continental sector due to the likely presence of reactive oxidation products formed from primary anthropogenic emissions, followed by the air coming from the Huelva sector because of the load of AVOCs (Sinha et al., 2012). As shown in Fig. 11, there is no clear difference between the background $\mathrm{OH}$ contributions to the total $\mathrm{OH}$ signal for the air arriving from those two different wind sectors indicating a similar influence on the background $\mathrm{OH}$ signal and a small contribution when compared to the $\mathrm{OH}$ background observed during the HUMPPA-COPEC 2010 where the measured BVOC concentrations were higher.

In summary, when the instrument was located within the canopy of a monoterpene-dominated forest environment with high BVOC concentrations and high $\mathrm{OH}$ reactivity, the $\mathrm{OH}$ measurements with HORUS was strongly affected by an interference resulting in a high background $\mathrm{OH}$ signal. Aged air masses containing oxidation products from anthropogenic emissions and primary AVOCs such as benzene and toluene measured in high concentrations during DOMINO 2008 seem to give rise to a smaller background $\mathrm{OH}$ signal. The HUMPPA-COPEC 2010 campaign was an extreme case where most of the total $\mathrm{OH}$ measured by the instrument was due to the background $\mathrm{OH}$ signal, in part because of the large background, but also because the atmospheric $\mathrm{OH}$ concentration was low. In contrast, during DOMINO $\mathrm{HO}_{\mathrm{x}}$ the total $\mathrm{OH}$ signal was not completely dominated by the contribution from the background signal even though the atmospheric $\mathrm{OH}$ concentration is comparable to that observed during HUMPPA-COPEC 2010. During HOPE 2012, a higher $\mathrm{OH}$ concentration in combination with a relatively low back- ground $\mathrm{OH}$ signal, comparable to that in DOMINO $\mathrm{HO}_{\mathrm{x}}$, makes the contribution of the background $\mathrm{OH}$ to the total $\mathrm{OH}$ small during daytime. It is also evident that for all three measurement campaigns performed with IPI nearly the entire nocturnal $\mathrm{OH}$ signal detected is due to the background $\mathrm{OH}$ in the instrument and not due to atmospheric $\mathrm{OH}$.

The background $\mathrm{OH}$ has an important impact on the measurement of the atmospheric concentration of the $\mathrm{OH}$ radical and it is likely to be observed also in the $\mathrm{HO}_{2}$ cell. During the HOPE 2012 campaign a background OH concentration of $1 \times 10^{6}$ molecules $\mathrm{cm}^{-3}$ was observed in the $\mathrm{HO}_{2}$ cell when no injection of $\mathrm{NO}$ was performed. As the atmospheric concentration of $\mathrm{HO}_{2}$ is of the order of $\sim 10^{8}$ $10^{7}$ molecules $\mathrm{cm}^{-3}$ the impact of this interference is below the precision of the instrument $\left(1.9 \times 10^{7}\right.$ molecules $\mathrm{cm}^{-3}$; Hens et al., 2014) and does not affect the $\mathrm{HO}_{2}$ radical measurements.

\subsection{Hypothesis about the origin of the background $\mathrm{OH}$}

\subsubsection{Instrumental tests}

The background $\mathrm{OH}$ measured with the HORUS instrument changes during the day and varies with different environments. As mentioned in the introduction, LIF-FAGE instruments are known to be affected by interferences (Holland and Hessling, 1995; Martinez et al., 2004); most of the known interferences are caused by laser photolysis or by fluorescence of other molecules in the vicinity of $308 \mathrm{~nm}$ wavelength. An interference caused by laser photolysis can be detected by observing a square dependency of the signal with laser power while a spectral interference can be eliminated by tuning the excitation laser on and off resonance with the $\mathrm{OH}$ transition line at $308 \mathrm{~nm}$. Interferences caused by laser photolysis occur when an atmospheric trace gas is photolysed by one photon of the laser beam and produces $\mathrm{OH}$ directly that can then be excited by a second photon of the same laser. This could happen, for example, with $\mathrm{HONO}, \mathrm{HNO}_{3}$ and $\mathrm{ROOH}$. Other species such as ozone and acetone can also be photolysed by the laser beam but, as the photolysis does not produce $\mathrm{OH}$ directly, the laser pulse of HORUS is too short ( $15 \mathrm{~ns})$ to allow the excitation of the resultant $\mathrm{OH}$ to happen within the same pulse. If the transport of these $\mathrm{OH}$ molecules out of the detection volume is sufficiently fast, the subsequent laser pulse will not be able to excite them. If the transport time is not sufficient, the subsequent pulse will excite the formed $\mathrm{OH}$. Both laser-generated interferences will show a square dependency with the laser power. Although interferences tests were performed on GTHOS (Ren et al., 2004), the HORUS instrument based on GTHOS also makes use of a White cell to increase the sensitivity of the $\mathrm{HO}_{\mathrm{x}}$ measurements. Test results for the species listed above (Ren et al., 2004) showed that the ambient concentration needed for these species to produce a detectable $\mathrm{OH}$ interference in the instrument has to be well above "usual" ambient conditions and higher than the values 


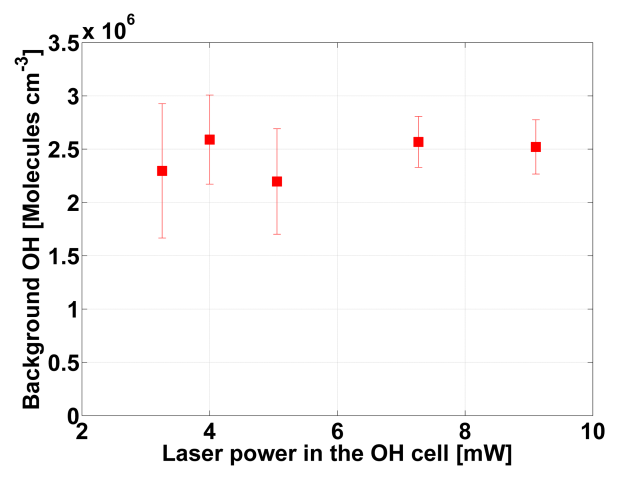

Figure 14. Background $\mathrm{OH}$ measured during the night (low variability) at five different values of laser power at the $\mathrm{OH}$ detection cell.

observed during the field campaigns described in this paper. Nevertheless, to test whether the origin of the background $\mathrm{OH}$ signal is photolytic, during the HUMPPA-COPEC 2010 and HOPE 2012 campaigns the laser power was varied by a factor of 4 . The background $\mathrm{OH}$ signal did not show any dependency when plotted against the laser power at the $\mathrm{OH}$ cell (Fig. 14). Therefore, we can exclude that the background $\mathrm{OH}$ signal is generated by the laser within the main air flow.

Since the residence time of an air parcel in the detection area of the White cell of HORUS instrument is more than two times shorter than the time period between two consecutive laser pulses at a laser repetition rate of $3000 \mathrm{~Hz}$, interferences due to double pulsing are unlikely to happen. Still, if air is collected in pockets in the White cell arms (Fig. 15) for an extended period of time there could be production of $\mathrm{OH}$. To inhibit this, the arms of the White cell are constantly flushed with synthetic air that avoids deposition of particles on the mirrors and prevents the air from becoming stagnant. In addition, baffles are mounted between the arms of the White cell and the detection cell helping to reduce the scatter light of the laser and reduce the opening between the White cell arms to the detection cell letting less air to pass. To confirm that we are not affected by formation of $\mathrm{OH}$ in pockets in the White cell arms, the flushing flow inside the White cell was increased by a factor of 2 . Figure 16 shows a test completed during HOPE 2012 in the evening, when the background OH was measured for different flushing flows in the cell. There is a general decreasing trend in the background $\mathrm{OH}$ due to ambient variability of the signal but no difference is observable when changing the flushing in the cell for two consecutive periods. No difference in the background $\mathrm{OH}$ was also observed when comparing the signal detected during night time with and without baffles and while flushing the White cell pockets with $\mathrm{C}_{3} \mathrm{~F}_{6}$, an $\mathrm{OH}$ scavenger, instead of with synthetic air. This confirms that the background $\mathrm{OH}$ signal in the detection volume is not formed in air pockets inside the White cell.

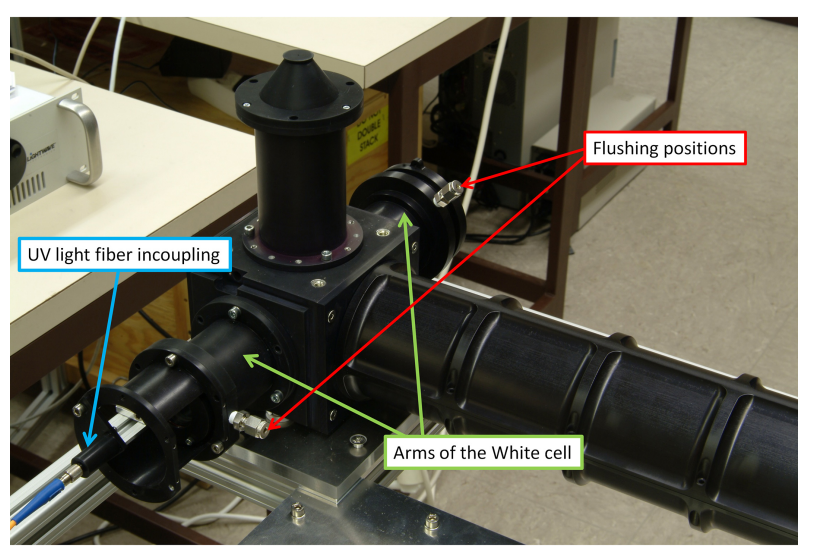

Figure 15. Picture of the White cell in use in the HORUS instrument highlighting arms and flushing positions of the White cell and position of the UV fibre incoupling.

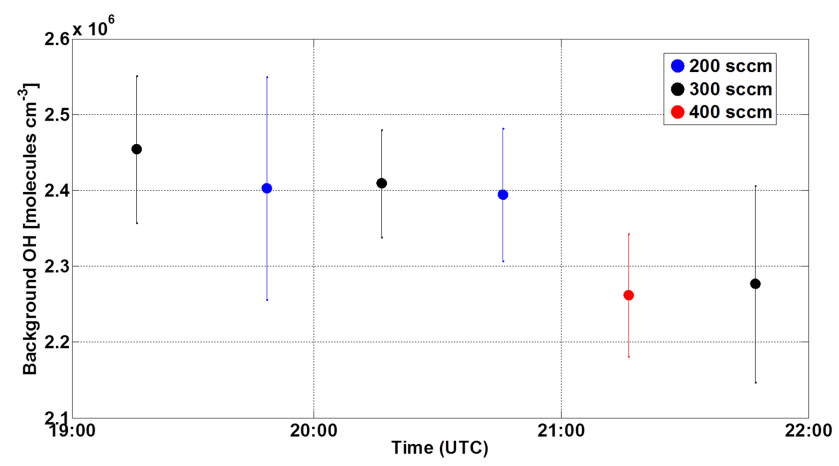

Figure 16. Background $\mathrm{OH}$ measured while changing the flushing inside the White cell. The circles represent the averages over $30 \mathrm{~min}$.

The background $\mathrm{OH}$ is also not formed by a leakage/back flushing of $\mathrm{NO}$ into the $\mathrm{OH}$ cell during the injection in the $\mathrm{HO}_{2}$ cell as no difference in the signal was observed during two consecutive periods with and without NO injection.

Finally, the possibility of formation of $\mathrm{OH}$ from reactions happening on walls was investigated by changing the material of the instrument inlet and by coating the inside walls with heavy water and detecting OD, but again no significant difference in the signal was observed nor was OD detected.

The results of the previously described tests show that it is unlikely that the background $\mathrm{OH}$ is an instrumental artefact and it is likely that the signal measured during field campaigns is caused by one or more atmospheric trace gases sampled by the instrument.

\subsubsection{Criegee intermediates hypothesis}

The pressure inside the instrument $(\sim 3.5 \mathrm{hPa})$ is such that bimolecular reactions with the concentrations of trace gases in the atmosphere are negligible in the transient time in the instrument. As laser photolysis and spectral interference can also be excluded from generating an $\mathrm{OH}$ signal within the 


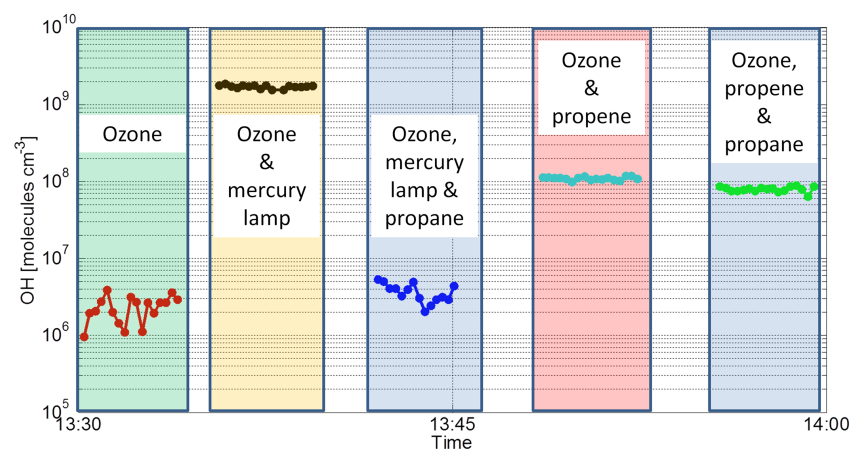

Figure 17. Ozonolysis test of propene in the presence of propane as an $\mathrm{OH}$ scavenger. The green shaded area represents the signal observed by HORUS when only ozone was injected in the flow tube. The yellow area shows the $\mathrm{OH}$ signal generated by photolysis of water. The first blue shaded area shows the reduction of the $\mathrm{OH}$ signal generated by photolysis of water after the addition of propane to the flow tube. The pink shaded area shows the signal measured while injecting ozone and propene into the flow tube. The second blue shaded area shows the small reduction observed in the signal when injecting propane into the flow tube to scavenge the $\mathrm{OH}$ produced.

HORUS instrument, one possible explanation for the background $\mathrm{OH}$ observed could be the unimolecular decomposition of an atmospheric trace gas species inside the instrument with formation of $\mathrm{OH}$. Possible candidates are Criegee intermediates formed during the ozonolysis of unsaturated compounds. Criegee intermediates are known to promptly decompose and produce $\mathrm{OH}$ at low pressure (Criegee, 1975; Neeb and Moortgat, 1999; Donahue et al., 2011; Vereecken and Francisco, 2012). To test for this within the HORUS instrument, an ozonolysis experiment with propene was performed at ambient pressure $(930 \mathrm{hPa})$ and temperature $(293 \mathrm{~K})$ in a flow tube connected to the inlet of HORUS. Initially, ozone $\left(1.3 \times 10^{13}\right.$ molecules $\left.\mathrm{cm}^{-3}\right)$, produced by passing pure oxygen in front of a mercury lamp, was injected into the flow tube (Fig. 17, green shaded area) at ambient pressure. Subsequently, a high concentration of $\mathrm{OH}$ was produced from photolysis of water by a mercury lamp, and introduced into the flow tube (Fig 17, yellow shaded area). Propane was then injected into the flow tube at a concentration of $2.5 \times 10^{16}$ molecules $\mathrm{cm}^{-3}$, enough to remove $99 \%$ of the observed $\mathrm{OH}$ (Fig. 17, blue shaded area). The mercury lamp was then removed and the propane injection was stopped. Only ozone and propene were injected into the flow tube (Fig. 17, orange shaded area). It is possible to observe a high $\mathrm{OH}$ signal generated from the ozonolysis of propene. To assess whether the $\mathrm{OH}$ is only formed in the flow tube at ambient pressure or partly in the low-pressure segment of the instrument, the same concentration of propane used to remove $99 \%$ of the $\mathrm{OH}$ produced from the photolysis of water was injected. It is possible to observe that, despite sending the same amount of propane, there is only a small reduction in the $\mathrm{OH}$ signal. As the concentration of propane injected

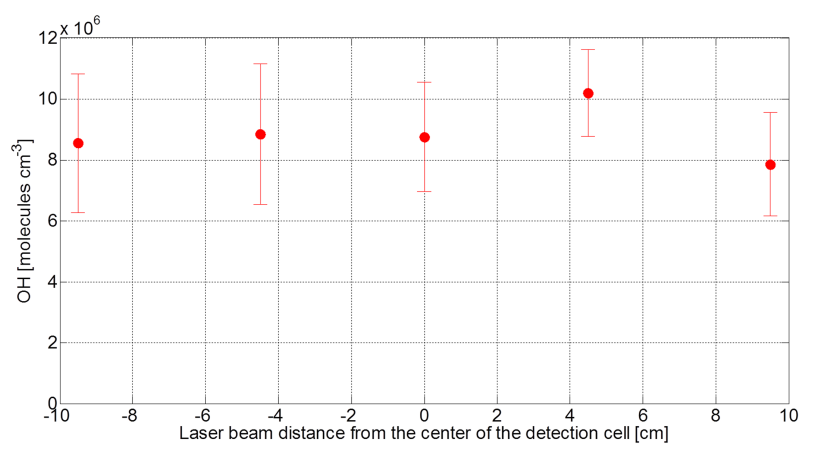

Figure 18. OH signal detected during the ozonolysis of propene in the presence of an $\mathrm{OH}$ scavenger for different positions of the laser beam inside the detection cell.

was sufficient to remove the $\mathrm{OH}$ generated in the flow tube at ambient pressure, the remaining $\mathrm{OH}$ still observed by HORUS has to be generated inside the low-pressure segment of the instrument. This test indicates how the HORUS instrument is sensitive to $\mathrm{OH}$ formed within the instrument during ozonolysis of propene. A more detailed description of the experimental setup together with modelling and a thorough description of the chemistry of Criegee intermediates and investigation of their impact on the IPI-LIF-FAGE can be found in Novelli et al. (2014). To understand whether the signal observed by HORUS during the ozonolysis of propene in the presence of an $\mathrm{OH}$ scavenger originated from walls or pockets of air in the White cell, the experiment was repeated using a single-pass setup. The dependency of the signal on the laser beam position within the detection cell was tested by moving the laser beam from the centre of the cell towards the sides. Figure 18 shows no clear dependency of the signal detected during ozonolysis of propene in the presence of an $\mathrm{OH}$ scavenger on the position of the laser beam. As for the background $\mathrm{OH}$ observed during field measurement, this confirms that the signal is not due to the White cell structure. The previous test indicates that the HORUS instrument is sensitive to $\mathrm{OH}$ formed within the instrument during ozonolysis of propene but more laboratory and field tests are necessary to completely ascertain whether the background $\mathrm{OH}$ observed during field campaigns entirely originates from the same chemical processes.

\section{Possible influence on earlier measurements}

The background $\mathrm{OH}$ signal depends on the type of environment and appears to be strongly related to the VOC concentration and type of VOC prevalent. It is possible that previous campaigns performed with LIF instruments without applying a chemical scavenger method have been affected by an interfering species in a similar manner as described in this manuscript. However, as underscored previously by Mao et al. (2012), the design of each particular LIF-FAGE system is likely to determine whether, and to what extent, 
the instrument suffers from this interference and so we will confine this discussion to the HORUS instrument.

The environment of previous campaigns may give an indication as to whether the measured $\mathrm{OH}$ was affected by significant inferences. The first campaign with HORUS consisted of a formal blind comparison, HOxCOMP, between several LIFs, a CIMS and a DOAS instrument both in a chamber and in ambient air. The results of the campaign are comprehensively described in Schlosser et al. (2009). During daytime, the agreement between all the instruments in the chamber was good with a regression slope between the MPI LIF and the FZJ-DOAS of one, but in ambient air the MPI LIF instrument measured higher concentrations of $\mathrm{OH}$ than the CIMS (Schlosser et al., 2009). As we noticed an unattributed change in the calibration factor of the instrument of $30 \%$, we cannot exclude a change in the same order of magnitude in the calibration source between the period in the chamber and in ambient that might explain the difference between the $\mathrm{OH}$ concentration measured by the MPI LIF and the one measured by the CIMS in ambient air. Night time data from HORUS are not shown either from the chamber period or in ambient air because of large unexplained measured $\mathrm{OH}$ signals up to $4 \times 10^{6}$ molecules $\mathrm{cm}^{-3}$ (Kubistin, 2009). Based on what we have learned since the use of IPI, it is likely that the high night time signal was due to a chemical interference in the HORUS instrument however, during daytime its concentration appeared to be low enough in that specific environment as to not produce a significant $\mathrm{OH}$ interference (i.e. within the accuracy of the instrument). Two subsequent campaigns, using HORUS, were performed without IPI. GABRIEL, an aircraft-based campaign, took place in October 2005 over the tropical rain forest in equatorial South America (Kubistin et al., 2010). Measured $\mathrm{OH}$ was much higher than predicted by a traditional chemical mechanism. Further analysis indicated that $\mathrm{OH}$ might be recycled within the isoprene degradation scheme (Lelieveld et al., 2008; Kubistin et al., 2010; Taraborrelli et al., 2012). Although without IPI we cannot completely rule out a possible interference for our measurements, laboratory tests and quantum mechanical calculation as follow-up studies to GABRIEL provided evidence for the proposed $\mathrm{OH}$ recycling, which was previously not accounted for (Dillon and Crowley, 2008; da Silva, 2010a; Peeters and Müller, 2010; Crounse et al., 2011). Even though laboratory (Crounse et al., 2011) and chamber studies (Fuchs et al., 2013) predict a smaller concentration of $\mathrm{OH}$ from the recycling of isoprene than reported in Lelieveld et al. (2008), measurements with a different LIF-FAGE instrument in the Borneo rainforest during the OP3 campaign (Whalley et al., 2011) also showed large discrepancies between measured and modelled $\mathrm{OH}$ using the traditional chemical mechanism. The elevated concentration of $\mathrm{OH}$ measured during OP3 was supported from co-measurements of formaldehyde and glyoxal made with a DOAS (Whalley et al., 2011). In addition, a side-byside airborne comparison between the aircraft configuration of the GTHOS LIF instrument (ATHOS - Airborne Tropospheric Hydrogen Oxides Sensor) employed without a chemical scavenger method and a CIMS (Ren et al., 2012), showed good agreement even at higher levels of isoprene. The aircraft campaign HOOVER, performed without IPI in the upper troposphere across Europe in September 2007 (Regelin et al., 2013), showed good agreement between the measured $\mathrm{OH}$ and a simple box model. This, together with the observations during other HORUS field campaigns and preliminary laboratory tests, suggests that the background $\mathrm{OH}$ observed by HORUS might be related to shorter-lived species, which likely do not have a significant impact on the upper troposphere due to the relatively large distance between the emission source and the measurement point.

\section{Conclusions}

An improved methodology to measure the $\mathrm{OH}$ radical with a LIF-FAGE instrument has been developed and deployed in three different environments. Results show that the use of the IPI-LIF-FAGE technique for HORUS results in good agreement with $\mathrm{OH}$ data measured with two different CIMS instruments during two campaigns. A thorough and careful characterisation of the operational parameters was necessary to find the optimum conditions to avoid inefficient mixing of the scavenger and the sampled air, excessive titration of $\mathrm{OH}$ in the low-pressure side of the instrument and large losses of $\mathrm{OH}$ on the walls of IPI. The best results were achieved when using propane as $\mathrm{OH}$ scavenger in a concentration of $2.5 \times 10^{15}$ molecules $\mathrm{cm}^{-3}$ with a carrier gas flow of at least $6000 \mathrm{sccm}$ and a residence time after the injection of the scavenger of $\sim 4 \mathrm{~ms}$. The use of a chemical scavenger method revealed the presence of a background $\mathrm{OH}$ signal that, using the same calibration factor as for atmospheric $\mathrm{OH}$, spanned a concentration of $5 \times 10^{5}$ to $1 \times 10^{7}$ molecules $\mathrm{cm}^{-3}$ in the environments described. Without the chemical scavenger method the atmospheric $\mathrm{OH}$ measured during the HUMPPA-COPEC 2010, DOMINO HO $\mathrm{HO}_{\mathrm{x}}$ and HOPE 2012 campaigns, during day and night time, would have been overestimated. Laboratory studies with HORUS (Novelli et al., 2014) show how the device is sensitive to $\mathrm{OH}$ formed within the instrument from unimolecular decomposition of Criegee intermediates, but more laboratory and field tests are necessary to clarify whether they represent the only source of the background $\mathrm{OH}$ observed during the field campaigns. It is, though, already clear that the background $\mathrm{OH}$ has a strong connection with the type of environment in which the instrument is deployed. Although it is very likely that the presence and extent of a chemical interference in different LIF-FAGE systems for the measurement of $\mathrm{OH}$ are dependent on the particular instrument design, our experience shows that the determination of the background $\mathrm{OH}$ should be a prerequisite for these systems and the ambient measurement of $\mathrm{OH}$. 
Acknowledgements. Work during HUMPPA-COPEC was supported by the Hyytiälä site engineers and staff. Support of the European Community Research Infrastructure Action under the FP6 "Structuring the European Research Area" Programme, EUSAAR Contract No. RII3-CT-2006-026140 is gratefully acknowledged. The HUMPPA-COPEC 2010 campaign measurements and analyses were supported by the ERC Grant ATMNUCLE (project No. 227463), Academy of Finland Centre of Excellence programme (project No. 1118615), the European integrated project on Aerosol Cloud Climate and Air Quality Interactions EUCAARI (project No. 036833-2), the EUSAAR TNA (project No. 400586) and the IMECC TA (project No. 4006261).

The work during HOPE 2012 was supported by the scientists and staff of DWD Hohenpeißenberg whom we would like to thank for providing the "platform" and opportunity to perform such campaigns devoted to a better process understanding of atmospheric chemistry. In particular, we thank Anja Werner, Jennifer Englert and Katja Michl for the VOC measurements, Stephan Gilge for the trace gases measurements and Georg Stange for running the CIMS.

We also would like to thank Gavin Phillips of the Department of Atmospheric Chemistry, MPIC for useful discussions and for assistance with the paper and Markus Rudolf for much technical support and guidance.

The service charges for this open access publication have been covered by the Max Planck Society.

Edited by: D. Heard

\section{References}

Atkinson, R., Baulch, D. L., Cox, R. A., Crowley, J. N., Hampson, R. F., Hynes, R. G., Jenkin, M. E., Rossi, M. J., Troe, J., and IUPAC Subcommittee: Evaluated kinetic and photochemical data for atmospheric chemistry: Volume II - gas phase reactions of organic species, Atmos. Chem. Phys., 6, 3625-4055, doi:10.5194/acp-6-3625-2006, 2006.

Berresheim, H., Elste, T., Plass-Dülmer, C., Eisele, F. L., and Tanner, D. J.: Chemical ionization mass spectrometer for long-term measurements of atmospheric $\mathrm{OH}$ and $\mathrm{H}_{2} \mathrm{SO}_{4}$, Int. J. Mass Spectrom., 202, 91-109, 2000.

Criegee, R.: Mechanism of Ozonolysis, Angew. Chem.-Int. Edit. Engl., 14, 745-752, 1975.

Crounse, J. D., Paulot, F., Kjaergaard, H. G., and Wennberg, P. O.: Peroxy radical isomerization in the oxidation of isoprene, Phys. Chem. Chem. Phys., 13, 13607-13613, 2011.

Crowley, J. N., Thieser, J., Tang, M. J., Schuster, G., Bozem, H., Beygi, Z. H., Fischer, H., Diesch, J.-M., Drewnick, F., Borrmann, S., Song, W., Yassaa, N., Williams, J., Pöhler, D., Platt, U., and Lelieveld, J.: Variable lifetimes and loss mechanisms for NO3 and N2O5 during the DOMINO campaign: contrasts between marine, urban and continental air, Atmos. Chem. Phys., 11, 10853-10870, doi:10.5194/acp-11-10853-2011, 2011

da Silva, G.: Hydroxyl radical regeneration in the photochemical oxidation of glyoxal: kinetics and mechanism of the $\mathrm{HC}(\mathrm{O}) \mathrm{CO}+$ $\mathrm{O}_{2}$ reaction, Phys. Chem. Chem. Phys., 12, 6698-6705, $2010 \mathrm{a}$.

da Silva, G.: Kinetics and Mechanism of the Glyoxal $+\mathrm{HO}_{2}$ Reaction: Conversion of $\mathrm{HO}_{2}$ to $\mathrm{OH}$ by Carbonyls, J. Phys. Chem. A, 115, 291-297, 2010b. da Silva, G.: Oxidation of Carboxylic Acids Regenerates Hydroxyl Radicals in the Unpolluted and Nighttime Troposphere, J. Phys. Chem. A, 114, 6861-6869, 2010c.

Di Carlo, P., Brune, W. H., Martinez, M., Harder, H., Lesher, R., Ren, X. R., Thornberry, T., Carroll, M. A., Young, V., Shepson, P. B., Riemer, D., Apel, E., and Campbell, C.: Missing OH reactivity in a forest: Evidence for unknown reactive biogenic VOCs, Science, 304, 722-725, 2004.

Dillon, T. J. and Crowley, J. N.: Direct detection of OH formation in the reactions of $\mathrm{HO}_{2}$ with $\mathrm{CH}_{3} \mathrm{C}(\mathrm{O}) \mathrm{O}_{2}$ and other substituted peroxy radicals, Atmos. Chem. Phys., 8, 4877-4889, doi:10.5194/acp-8-4877-2008, 2008.

Donahue, N. M., Drozd, G. T., Epstein, S. A., Presto, A. A., and Kroll, J. H.: Adventures in ozoneland: down the rabbit-hole, Phys. Chem. Chem. Phys., 13, 10848-10857, 2011.

Eisele, F. L. and Tanner, D. J.: Ion-assisted tropospheric OH measurements, J. Geophys. Res.-Atmos., 96, 9295-9308, 1991.

Eisele, F. L., Mauldin, R. L., Tanner, D. J., Fox, J. R., Mouch, T., and Scully, T.: An inlet/sampling duct for airborne OR and sulfuric acid measurements, J. Geophys. Res.-Atmos., 102, 2799328001, 1997.

Eisele, F. L., Mauldin, R. L., Tanner, D. J., Cantrell, C., Kosciuch, E., Nowak, J. B., Brune, B., Faloona, I., Tan, D., Davis, D. D., Wang, L., and Chen, G.: Relationship between OH measurements on two different NASA aircraft during PEM Tropics B, J. Geophys. Res.-Atmos., 106, 32683-32689, 2001.

Faloona, I., Tan, D., Brune, W., Hurst, J., Barket, D., Couch, T. L., Shepson, P., Apel, E., Riemer, D., Thornberry, T., Carroll, M. A., Sillman, S., Keeler, G. J., Sagady, J., Hooper, D., and Paterson, K.: Nighttime observations of anomalously high levels of hydroxyl radicals above a deciduous forest canopy, J. Geophys. Res.-Atmos., 106, 24315-24333, 2001.

Faloona, I., Tan, D., Lesher, R., Hazen, N., Frame, C., Simpas, J., Harder, H., Martinez, M., Di Carlo, P., Ren, X., and Brune, W.: A Laser-induced Fluorescence Instrument for Detecting Tropospheric $\mathrm{OH}$ and $\mathrm{HO}_{2}$ : Characteristics and Calibration, J. Atmos. Chem., 47, 139-167, 2004.

Fuchs, H., Hofzumahaus, A., Rohrer, F., Bohn, B., Brauers, T., Dorn, H. P., Haseler, R., Holland, F., Kaminski, M., Li, X., Lu, K., Nehr, S., Tillmann, R., Wegener, R., and Wahner, A.: Experimental evidence for efficient hydroxyl radical regeneration in isoprene oxidation, Nat. Geosci., 6, 1023-1026, doi:10.1038/ngeo1964, 2013.

Handisides, G. M., Plass-Dülmer, C., Gilge, S., Bingemer, H., and Berresheim, H.: Hohenpeissenberg Photochemical Experiment (HOPE 2000): Measurements and photostationary state calculations of $\mathrm{OH}$ and peroxy radicals, Atmos. Chem. Phys., 3, 15651588, doi:10.5194/acp-3-1565-2003, 2003.

Hard, T. M., O’Brien, R. J., Chan, C. Y., and Mehrabzadeh, A. A.: Tropospheric free radical determination by fluorescence assay with gas expansion, Environ. Sci. Technol., 18, 768-777, 1984.

Hens, K., Novelli, A., Martinez, M., Auld, J., Axinte, R., Bohn, B., Fischer, H., Keronen, P., Kubistin, D., Nölscher, A. C., Oswald, R., Paasonen, P., Petäjä, T., Regelin, E., Sander, R., Sinha, V., Sipilä, M., Taraborrelli, D., Tatum Ernest, C., Williams, J., Lelieveld, J., and Harder, H.: Observation and modelling of $\mathrm{HO}_{\mathrm{x}}$ radicals in a boreal forest, Atmos. Chem. Phys., 14, 8723-8747, doi:10.5194/acp-14-8723-2014, 2014. 
Hofzumahaus, A., Aschmutat, U., Brandenburger, U., Brauers, T., Dorn, H. P., Hausmann, M., Heßling, M., Holland, F., PlassDülmer, C., and Ehhalt, D. H.: Intercomparison of Tropospheric $\mathrm{OH}$ Measurements by Different Laser Techniques during the POPCORN Campaign 1994, J. Atmos. Chem., 31, 227-246, 1998.

Hofzumahaus, A., Rohrer, F., Lu, K., Bohn, B., Brauers, T., Chang, C.-C., Fuchs, H., Holland, F., Kita, K., Kondo, Y., Li, X., Lou, S., Shao, M., Zeng, L., Wahner, A., and Zhang, Y.: Amplified Trace Gas Removal in the Troposphere, Science, 324, 17021704, 2009.

Holland, F. and Hessling, M.: In situ measurement of tropospheric $\mathrm{OH}$ radicals by laser-induced fluorescence, J. Atmos. Sci., 52, 3393-3401, 1995.

Junninen, H., Lauri, A., Keronen, P., Aalto, P., Hiltunen, V., Hari, P., and Kulmala, M.: Smart-SMEAR: on-line data exploration and visualization tool for SMEAR stations, Boreal Env. Res., 14, 447-457, 2009.

Kubistin, D.: $\mathrm{OH}$ und $\mathrm{HO}_{2}$ Radikale uber dem tropischen Regenwald, Physics, Johannes Gutenberg Univeristät, Germany, Mainz, 2009.

Kubistin, D., Harder, H., Martinez, M., Rudolf, M., Sander, R., Bozem, H., Eerdekens, G., Fischer, H., Gurk, C., Klüpfel, T., Königstedt, R., Parchatka, U., Schiller, C. L., Stickler, A., Taraborrelli, D., Williams, J., and Lelieveld, J.: Hydroxyl radicals in the tropical troposphere over the Suriname rainforest: comparison of measurements with the box model MECCA, Atmos. Chem. Phys., 10, 9705-9728, doi:10.5194/acp-10-97052010, 2010.

Lelieveld, J., Butler, T. M., Crowley, J. N., Dillon, T. J., Fischer, H., Ganzeveld, L., Harder, H., Lawrence, M. G., Martinez, M., Taraborrelli, D., and Williams, J.: Atmospheric oxidation capacity sustained by a tropical forest, Nature, 452, 737-740, 2008.

Levy, H.: Normal Atmosphere - Large radical and formaldehyde concentrations predicted, Science, 173, 141-143, 1971.

Levy, H.: Photochemistry of the Troposphere, in: Advances in Photochemistry, John Wiley \& Sons, Inc., 1974.

Mao, J., Ren, X., Zhang, L., Van Duin, D. M., Cohen, R. C., Park, J.-H., Goldstein, A. H., Paulot, F., Beaver, M. R., Crounse, J. D., Wennberg, P. O., DiGangi, J. P., Henry, S. B., Keutsch, F. N., Park, C., Schade, G. W., Wolfe, G. M., Thornton, J. A., and Brune, W. H.: Insights into hydroxyl measurements and atmospheric oxidation in a California forest, Atmos. Chem. Phys., 12, 8009-8020, doi:10.5194/acp-12-8009-2012, 2012.

Martinez, M., Harder, H., Ren, X., Lesher, R. L., and Brune, W. H.: Measuring atmospheric naphthalene with laser-induced fluorescence, Atmos. Chem. Phys., 4, 563-569, doi:10.5194/acp-4-5632004, 2004.

Martinez, M., Harder, H., Kubistin, D., Rudolf, M., Bozem, H., Eerdekens, G., Fischer, H., Klüpfel, T., Gurk, C., Königstedt, R., Parchatka, U., Schiller, C. L., Stickler, A., Williams, J., and Lelieveld, J.: Hydroxyl radicals in the tropical troposphere over the Suriname rainforest: airborne measurements, Atmos. Chem. Phys., 10, 3759-3773, doi:10.5194/acp-10-3759-2010, 2010.

Neeb, P. and Moortgat, G. K.: Formation of $\mathrm{OH}$ radicals in the gas-phase reaction of propene, isobutene, and isoprene with $\mathrm{O}_{3}$ : Yields and mechanistic implications, J. Phys. Chem. A, 103, 9003-9012, 1999.
Nölscher, A. C., Williams, J., Sinha, V., Custer, T., Song, W., Johnson, A. M., Axinte, R., Bozem, H., Fischer, H., Pouvesle, N., Phillips, G., Crowley, J. N., Rantala, P., Rinne, J., Kulmala, M., Gonzales, D., Valverde-Canossa, J., Vogel, A., Hoffmann, T., Ouwersloot, H. G., Vilà-Guerau de Arellano, J., and Lelieveld, J.: Summertime total $\mathrm{OH}$ reactivity measurements from boreal forest during HUMPPA-COPEC 2010, Atmos. Chem. Phys., 12, 8257-8270, doi:10.5194/acp-12-8257-2012, 2012.

Novelli, A., Vereecken, L., Lelieveld, J., and Harder, H.: Direct observation of $\mathrm{OH}$ formation from stabilised Criegee intermediates, Phys. Chem. Chem. Phys., 16, 19941-19951, 2014.

Peeters, J. and Müller, J.-F.: $\mathrm{HO}_{\mathrm{x}}$ radical regeneration in isoprene oxidation via peroxy radical isomerisations. II: experimental evidence and global impact, Phys. Chem. Chem. Phys., 12, 14227 14235, 2010.

Peeters, J., Nguyen, T. L., and Vereecken, L.: $\mathrm{HO}_{\mathrm{x}}$ radical regeneration in the oxidation of isoprene, Phys. Chem. Chem. Phys., 11, 5935-5939, 2009.

Perner, D., Platt, U., Trainer, M., Hübler, G., Drummond, J., Junkermann, W., Rudolph, J., Schubert, B., Volz, A., Ehhalt, D. H., Rumpel, K. J., and Helas, G.: Measurements of tropospheric $\mathrm{OH}$ concentrations: A comparison of field data with model predictions, J. Atmos. Chem., 5, 185-216, 1987.

Petäjä, T., Mauldin, III, R. L., Kosciuch, E., McGrath, J., Nieminen, T., Paasonen, P., Boy, M., Adamov, A., Kotiaho, T., and Kulmala, M.: Sulfuric acid and $\mathrm{OH}$ concentrations in a boreal forest site, Atmos. Chem. Phys., 9, 7435-7448, doi:10.5194/acp9-7435-2009, 2009.

Regelin, E., Harder, H., Martinez, M., Kubistin, D., Tatum Ernest, C., Bozem, H., Klippel, T., Hosaynali-Beygi, Z., Fischer, H., Sander, R., Jöckel, P., Königstedt, R., and Lelieveld, J.: $\mathrm{HO}_{\mathrm{x}}$ measurements in the summertime upper troposphere over $\mathrm{Eu}-$ rope: a comparison of observations to a box model and a 3-D model, Atmos. Chem. Phys., 13, 10703-10720, doi:10.5194/acp13-10703-2013, 2013.

Ren, X., Harder, H., Martinez, M., Faloona, I., Tan, D., Lesher, R., Di Carlo, P., Simpas, J., and Brune, W.: Interference Testing for Atmospheric $\mathrm{HO}_{\mathrm{x}}$ Measurements by Laser-induced Fluorescence, J. Atmos. Chem., 47, 169-190, 2004.

Ren, X., Olson, J. R., Crawford, J. H., Brune, W. H., Mao, J., Long, R. B., Chen, Z., Chen, G., Avery, M. A., Sachse, G. W., Barrick, J. D., Diskin, G. S., Huey, L. G., Fried, A., Cohen, R. C., Heikes, B., Wennberg, P. O., Singh, H. B., Blake, D. R., and Shetter, R. E.: $\mathrm{HO}_{\mathrm{x}}$ chemistry during INTEX-A 2004: Observation, model calculation, and comparison with previous studies, J. Geophys. Res.-Atmos., 113, D05310, doi:10.1029/2007jd009166,2008.

Ren, X., Mao, J., Brune, W. H., Cantrell, C. A., Mauldin III, R. L., Hornbrook, R. S., Kosciuch, E., Olson, J. R., Crawford, J. H., Chen, G., and Singh, H. B.: Airborne intercomparison of HOx measurements using laser-induced fluorescence and chemical ionization mass spectrometry during ARCTAS, Atmos. Meas. Tech., 5, 2025-2037, doi:10.5194/amt-5-2025-2012, 2012.

Sander, S. P., Abbatt, J., Barker, J. R., Burkholder, J. B., Friedl, R. R., Golden, D. M., Huie, R. E., Kolb, C. E., Kurylo, M. J., Moortgat, G. K., Orkin, V. L., and Wine, P. H.: Chemical Kinetics and Photochemical Data for Use in Atmospheric Studies, Evaluation No. 17, JPL Publication 10-6 Jet Propulsion Laboratory Pasadena, California, 2011. 
Schlosser, E., Bohn, B., Brauers, T., Dorn, H.-P., Fuchs, H., Häseler, R., Hofzumahaus, A., Holland, F., Rohrer, F., Rupp, L., Siese, M., Tillmann, R., and Wahner, A.: Intercomparison of Two Hydroxyl Radical Measurement Techniques at the Atmosphere Simulation Chamber SAPHIR, J. Atmos. Chem., 56, 187-205, 2007.

Schlosser, E., Brauers, T., Dorn, H.-P., Fuchs, H., Häseler, R., Hofzumahaus, A., Holland, F., Wahner, A., Kanaya, Y., Kajii, Y., Miyamoto, K., Nishida, S., Watanabe, K., Yoshino, A., Kubistin, D., Martinez, M., Rudolf, M., Harder, H., Berresheim, H., Elste, T., Plass-Dülmer, C., Stange, G., and Schurath, U.: Technical Note: Formal blind intercomparison of $\mathrm{OH}$ measurements: results from the international campaign HOxComp, Atmos. Chem. Phys., 9, 7923-7948, doi:10.5194/acp-9-7923-2009, 2009.

Sinha, V., Williams, J., Diesch, J. M., Drewnick, F., Martinez, M., Harder, H., Regelin, E., Kubistin, D., Bozem, H., HosaynaliBeygi, Z., Fischer, H., Andrés-Hernández, M. D., Kartal, D., Adame, J. A., and Lelieveld, J.: Constraints on instantaneous ozone production rates and regimes during DOMINO derived using in-situ $\mathrm{OH}$ reactivity measurements, Atmos. Chem. Phys., 12, 7269-7283, doi:10.5194/acp-12-7269-2012, 2012.

Song, W., Williams, J., Yassaa, N., Martinez, M., Carnero, J., Hidalgo, P., Bozem, H., and Lelieveld, J.: Winter and summer characterization of biogenic enantiomeric monoterpenes and anthropogenic BTEX compounds at a Mediterranean Stone Pine forest site, J. Atmos. Chem., 68, 233-250, 2011.

Taraborrelli, D., Lawrence, M. G., Crowley, J. N., Dillon, T. J., Gromov, S., Groß, C. B. M., Vereecken, L., and Lelieveld, J.: Hydroxyl radical buffered by isoprene oxidation over tropical forests, Nat. Geosci., 5, 190-193, 2012.

Vereecken, L. and Francisco, J. S.: Theoretical studies of atmospheric reaction mechanisms in the troposphere, Chem. Soc. Rev., 41, 6259-6293, 2012.

Wennberg, P. O., Cohen, R. C., Hazen, N. L., Lapson, L. B., Allen, N. T., Hanisco, T. F., Oliver, J. F., Lanham, N. W., Demusz, J. N., and Anderson, J. G.: Aircraft-borne, laser-induced fluorescence instrument for the in situ detection of hydroxyl and hydroperoxyl radicals, Rev. Sci. Instrum., 65, 1858-1876, 1994.
Whalley, L. K., Edwards, P. M., Furneaux, K. L., Goddard, A., Ingham, T., Evans, M. J., Stone, D., Hopkins, J. R., Jones, C. E., Karunaharan, A., Lee, J. D., Lewis, A. C., Monks, P. S., Moller, S. J., and Heard, D. E.: Quantifying the magnitude of a missing hydroxyl radical source in a tropical rainforest, Atmos. Chem. Phys., 11, 7223-7233, doi:10.5194/acp-11-7223-2011, 2011.

White, J. U.: Long optical paths of large aperture, J. Opt. Soc. Am., 32, 285-288, 1942.

Williams, J., Crowley, J., Fischer, H., Harder, H., Martinez, M., Petäjä, T., Rinne, J., Bäck, J., Boy, M., Dal Maso, M., Hakala, J., Kajos, M., Keronen, P., Rantala, P., Aalto, J., Aaltonen, H., Paatero, J., Vesala, T., Hakola, H., Levula, J., Pohja, T., Herrmann, F., Auld, J., Mesarchaki, E., Song, W., Yassaa, N., Nölscher, A., Johnson, A. M., Custer, T., Sinha, V., Thieser, J., Pouvesle, N., Taraborrelli, D., Tang, M. J., Bozem, H., Hosaynali-Beygi, Z., Axinte, R., Oswald, R., Novelli, A., Kubistin, D., Hens, K., Javed, U., Trawny, K., Breitenberger, C., Hidalgo, P. J., Ebben, C. J., Geiger, F. M., Corrigan, A. L., Russell, L. M., Ouwersloot, H. G., Vilà-Guerau de Arellano, J., Ganzeveld, L., Vogel, A., Beck, M., Bayerle, A., Kampf, C. J., Bertelmann, M., Köllner, F., Hoffmann, T., Valverde, J., González, D., Riekkola, M.-L., Kulmala, M., and Lelieveld, J.: The summertime Boreal forest field measurement intensive (HUMPPA-COPEC-2010): an overview of meteorological and chemical influences, Atmos. Chem. Phys., 11, 10599-10618, doi:10.5194/acp-11-10599-2011, 2011.

Yassaa, N., Song, W., Lelieveld, J., Vanhatalo, A., Bäck, J., and Williams, J.: Diel cycles of isoprenoids in the emissions of Norway spruce, four Scots pine chemotypes, and in Boreal forest ambient air during HUMPPA-COPEC-2010, Atmos. Chem. Phys., 12, 7215-7229, doi:10.5194/acp-12-7215-2012, 2012.

York, D., Evensen, N. M., Martínez, M. L., and De Basabe Delgado, J.: Unified equations for the slope, intercept, and standard errors of the best straight line, Am. J. Phys., 72, 367-375, 2004. 